\title{
On the misidentification of chalcid (Hymenoptera: Chalcidoidea) parasitoids of the cabbage seedpod weevil (Coleoptera: Curculionidae) in North America
}

\author{
Gary A.P. Gibson ${ }^{1}$ \\ Agriculture and Agri-Food Canada, Biodiversity and Integrated Pest Management, \\ K.W. Neatby Building, 960 Carling Avenue, Ottawa, Ontario, Canada K1A 0C6
}

\section{Hannes Baur}

Department of Invertebrates, Naturhistorisches Museum, Bernstrasse 15, CH-3005

Bern, Switzerland

\section{Bryan Ulmer, Lloyd Dosdall}

Department of Agricultural, Food and Nutritional Science, 4-10 Agriculture/Forestry Centre, University of Alberta, Edmonton, Alberta, Canada T6G 2P5

\section{Franck Muller}

CABI Bioscience Centre, Rue des Grillons, Delémont, Switzerland

\begin{abstract}
Previous identifications in North America of Trichomalus perfectus (Walker, 1835) and Mesopolobus morys (Walker, 1848) (Chalcidoidea: Pteromalidae), the principal chalcid parasitoids of the cabbage seedpod weevil (Ceutorhynchus obstrictus Marsham, 1802) in Europe, are shown to be misidentifications of Trichomalus lucidus (Walker, 1835) and Mesopolobus (Xenocrepis) moryoides sp. nov., respectively. Necremnus duplicatus Gahan, 1941 (Chalcidoidea: Eulophidae) is synonymized formally under Necremnus tidius (Walker, 1839) syn. nov., confirming a previous, tentative synonymy. Both sexes of $N$. tidius, M. moryoides, and T. lucidus are illustrated and compared with those of similar species using macrophotography and scanning electron microphotography. Hypotheses are offered to explain why the principal chalcid parasitoids of the cabbage seedpod weevil differ between North America and Europe and how the three treated species came to be in North America.
\end{abstract}

Résumé-Les insectes connus jusqu'ici en Amérique du Nord comme Trichomalus perfectus (Walker, 1835) et Mesopolobus morys (Walker, 1848) (Chalidoidea : Pteromalidae), les principaux chalcidiens parasitoïdes du charaçon de la graine de chou (Ceutorhynchus obstrictus Marsham, 1802) en Europe, sont mal identifiés; il s'agit, en fait, respectivement de Trichomalus lucidus (Walker, 1835) et de Mesopolobus (Xenocrepis) moryoides sp. nov. Necremnus duplicatus Gahan, 1941 (Chalcidoidea : Eulophidae) devient formellement un synonyme plus récent de Necremnus tidius (Walker, 1839) syn. nov., confirmant ainsi une synonymie préliminaire antérieure. Des macrophotographies et des microphotographies au microscope électronique à balayage viennent illustrer les deux sexes de $N$. tidius, de $M$. moryoides et de $T$. lucidus et permettent des comparaisons avec les espèces similaires. Des hypothèses cherchent à expliquer pourquoi les chalcidiens parasitoïdes du charançon de la graine de chou sont différents en Amérique du Nord et en Europe et comment les trois espèces en question se sont retrouvées en Amérique du Nord.

[Traduit par la Rédaction]

\section{Introduction}

Received 18 January 2005. Accepted 13 May 2005.

${ }^{1}$ Corresponding author (e-mail: gibsong@agr.gc.ca).
The cabbage seedpod weevil, Ceutorhynchus obstrictus Marsham, $1802 \quad(=$ C. assimilis (Paykull, 1792)) (Coleoptera: Curculionidae), 
was introduced from Europe to western North America about 70 years ago. Its host range includes plants of the family Brassicaceae. The weevil initially was a pest of mustard, cabbage, turnip, rutabaga, and Brussels sprouts (Brassica spp.) grown for seed (Hanson et al. 1948; Carlson et al. 1951; Walz 1957). Since its introduction it has become an invasive pest throughout much of North America north of Mexico (Brodeur et al. 2001; Cárcamo et al. 2001; Mason et al. 2004) and a major economic pest of brassicaceous oilseed crops including canola and rape (Brassica napus L. and B. rapa L.) (Buntin et al. 1995; Dosdall et al. 2001).

The first documented presence of C. obstrictus in North America was from adults collected in 1931 in Vancouver, British Columbia, Canada (Hanson et al. 1948). Baker (1936) subsequently reared specimens from mustard seedpods in Washington State, United States of America, along with four hymenopterous parasitoids that were stated to represent at least two distinct groups. Although these specimens were not identified and have not been located, later rearings indicate they undoubtedly were chalcids. Gahan (1941) described parasitoids reared from $C$. obstrictus in turnip seedpods collected in Washington in 1937 as a new species, Necremnus duplicatus (Eulophidae). In addition to the reared series, Gahan also had several specimens that he did not include in the type series but which he stated seemed to be the same species, including two individuals from the Netherlands reared from Brassicaceae pods. Bouček (1959) later suggested that $N$. duplicatus is very near, if not identical, to the European species Necremnus tidius (Walker, 1839). Two other chalcid species were also reared from $C$. obstrictus soon after its initial discovery in Washington and subsequently identified as European species. Doucette (1944) reared an unidentified species of Amblymerus Walker, which was identified as Disema sp. in Doucette (1948), Xenocrepis sp. in Hanson et al. (1948), and Xenocrepis pura Mayr in Walz (1957). These names are now recognized as junior synonyms of Mesopolobus Westwood (1833) and Mesopolobus morys (Walker, 1848) (Pteromalidae), respectively (Graham 1957). Both Doucette (1944) and Breakey et al. (1944) also reared a species initially identified as Trichomalus fasciatus (Thomson, 1878) (Pteromalidae), which was a previously known parasitoid of C. obstrictus in Europe (Heymons 1921). However, Graham (1956) subsequently synonymized $T$. fasciatus under Trichomalus lucidus (Walker, 1835), and Delucchi and Graham (1956) stated that all literature records referring to $T$. fasciatus as a parasitoid of C. obstrictus probably were based on misidentifications of Trichomalus perfectus (Walker, 1835). Using the description of $T$. perfectus provided by Delucchi and Graham (1956), Peck (1963) identified individuals of a Trichomalus species reared from $C$. obstrictus in British Columbia as $T$. perfectus. Ever since then, this name has been used for the Trichomalus species parasitizing $C$. obstrictus in western North America. It was also used by Buntin (1998) for parasitoids reared from the seedpods of B. napus in Georgia, United States of America, the only locality in eastern North America for which parasitoids of $C$. obstrictus have been reported.

The species identified as $M$. morys and T. perfectus were not reported in North America prior to being reared from $C$. obstrictus soon after the first recorded occurrence of this weevil. Therefore, it has long been assumed that both the parasitoid species and $C$. obstrictus were introduced together in seed shipments (Hanson et al. 1948; McLeod 1953). Trichomalus perfectus and $M$. morys are the principal chalcid parasitoids of $C$. obstrictus in Europe, where parasitism rates typically exceed $50 \%$, can reach $90 \%$, and can be high even at low pest densities (Buntin 1998; Murchie and Williams 1998). Trichomalus perfectus, $M$. morys, and N. duplicatus have been reported as the most important parasitoids of C. obstrictus in North America (Kuhlmann et al. 2002), but parasitism rates are generally much lower than those found in Europe (Harmon and McCaffrey 1997; Buntin 1998).

In their review of the scientific literature relating to parasitoids of the cabbage seedpod weevil, Murchie and Williams (1998, p. 165) stated that "the study of literature is hampered by synonymy and misidentification". During the course of identifying chalcid parasitoids of the cabbage seedpod weevil in western Canada, we confirmed that $N$. duplicatus is a junior synonym of $N$. tidius, as has long been speculated. We also discovered that the species reported in the North American literature as $T$. perfectus and M. morys have been consistently misidentified. The species identified as $T$. perfectus is T. lucidus, which is reported as a principal parasitoid of Ceutorhynchus alliariae Brisout, 1860 and Ceutorhynchus roberti Gyllenhal, 
1837 in Switzerland but is not known to be a common parasitoid of $C$. obstrictus in Europe (Klander 2001; Muller et al. 2004). The species identified as $M$. morys represents a new species of uncertain area of origin. In this paper we describe the new Mesopolobus species and differentiate its dimorphic sexes from those of similar European species, provide features to differentiate $T$. lucidus from $T$. perfectus, and formalize the synonymy of $N$. duplicatus under $N$. tidius. This is done to clarify the nomenclature and to provide evidence that North America lacks all the principal chalcid biological control agents of $C$. obstrictus found on canola in Europe.

\section{Materials and methods}

This study is based on voucher specimens of species previously reported in the literature as reared from $C$. obstrictus in Canada and the United States of America, specimens reared from canola and rape seedpods in Alberta and Saskatchewan during 2002 and 2003, specimens reared from Ceutorhynchus species in Germany and Switzerland during 2000-2003, and other specimens of relevant species in the following collections. An asterisk before a codon indicates a collection in which cited type material that was not examined is deposited.

BMNH The Natural History Museum, London, United Kingdom

CNC Canadian National Collection of Insects and Arachnids, Ottawa, Ontario, Canada

MTJP Maurice T. James Entomological Collection, Pullman, Washington, United States of America

MZLU Museum of Zoology, Lund University, Lund, Sweden

NMBS Naturhistorisches Museum, Bern, Switzerland

*NMWA Naturhistorisches Museum, Vienna, Austria

OSAC Oregon State Arthropod Collection, Oregon State University, Corvallis, Oregon, United States of America

*OXUM Hope Entomological Collections, Oxford University Museum of Natural History, Oxford, United Kingdom

UCDC Bohart Museum of Entomology, University of California, Davis, California, United States of America
UGCA University of Georgia Museum of Natural History, Athens, Georgia, United States of America

USNM United States National Museum of Natural History, Washington, District of Columbia, United States of America

WFBM William F. Barr Entomological Museum, University of Idaho, Moscow, Idaho, United States of America

WFIC Western Forest Insect Collection, Corvallis, Oregon, United States of America

Our initial concepts of European Mesopolobus and Trichomalus were based on Graham (1969), of European Necremnus on Bouček (1959) and Graham (1959), and of Nearctic Necremnus on Gahan (1941). Type material of the senior synonym of putative species was then examined to verify these concepts, which confirmed that valid species names were available for the North American species of Necremnus and Trichomalus. Type material of the junior synonyms of relevant names in these genera was not examined because this study is not a taxonomic revision, and the lists of synonyms we provide follow the above authors and Noyes (2002). Type material in the $\mathrm{BMNH}$ of both the senior and junior synonyms of species assigned to Mesopolobus (Xenocrepis) was examined to substantiate that a name was not available for the species of Mesopolobus reared from C. obstrictus in North America.

Unless stated otherwise, specimens cited under "Material examined" from localities in Canada are deposited in the CNC, and those cited from localities in the United States are deposited in the USNM. Collection data cited for material examined have been standardized; C. obstrictus has been substituted for either C. assimilis or variants of "cabbage seedpod weevil" in the original label data, and county names have been included for all United States collection localities. A date preceded by "em." is the emergence date, and "HP" refers to host plant. Scientific and common names of Brassicaceae species follow Warwick et al. (2004). Names of most collectors have been abbreviated to save space, as follows: AF, A. Fox; AJH, A.J. Hanson; AJW, A.J. Walz; BH, B. Harmon; B\&O, M. Braun and O. Olfert; CFD, C.F. Doucette; DEF, D.E. Fox; DJS, D.J. Schotzko; ECC, E.C. Carlson; GDB, G.D. 
Buntin; GY, G. Yamanaka; JM, J. McLeod; RB, R. Bazett; RG, R. Glendenning; RLD, R.L. Doutt; U\&D, B. Ulmer and L. Dosdall; and WHL, W.H. Lange.

Terms for structure and sculpture follow Gibson $(1995,1997)$ and Gibson (2003), respectively. The treated genera can be distinguished from other genera of Eulophidae and Pteromalidae in North America using the keys of Schauff et al. (1997) and Bouček and Heydon (1997), respectively. The diagnosis provided for each species includes only those features that serve to differentiate it within its respective genus, though in combination the features are sufficient to distinguish the species from all other known parasitoids of C. obstrictus in North America. Descriptions are based on observations made by the senior author using a Nikon SMZ-1500 microscope fitted with a 10-mm ocular grid having 100 divisions, with an incandescent light source and a translucent acetate diffuser to reduce glare. Absolute measurements provided as parts of ratios of body parts for $M$. moryoides were taken at a magnification where 10 units $=0.8 \mathrm{~mm}$. Forewings were photographed using a compound microscope. These images and scanning electron microphotographs were digitally retouched using Adobe Photoshop ${ }^{\mathrm{TM}}$ to enhance clarity.

\section{Species treatments}

\section{Necremnus tidius (Walker)}

(Figs. 1, 3, 5, 29)

Eulophus tidius Walker, 1839: 146-147. Syntype $0^{\pi}$ (BMNH, examined).

Eulophus zeugma Walker, 1839: 183. Syntype ㅇ (BMNH); synonymy by Bouček and Askew 1968: 67.

Eulophus metanira Walker, 1839: 183-184. Lectotype + (OXUM) designated by Graham 1991: 8; synonymy by Graham 1991: 8 .

Eulophus hippia Walker, 1839: 184. Syntype 우 (BMNH); synonymy by Bouček and Askew 1968: 67.

Eulophus mamurius Walker, 1848: 232. Syntype $\sigma^{\pi}(\mathrm{BMNH})$; synonymy by Bouček and Askew 1968: 67.

Entedon cyrinus Goureau, 1851: 143, pl. 5, no. 5, Figs. 5-7. Syntype 우 (OXUM); synonymy by Graham 1963: 190.
Necremnus duplicatus Gahan, 1941: 201-203. Holotype o (USNM, examined). New synonymy. Breakey et al. 1944: 118; Doucette 1944: 124; Doucette 1948: 764; Hanson et al. 1948: 14, 15; Carlson et al. 1950: 390; McLeod 1953: 13, 16; Walz 1957: 220; Peck 1963: 100; Murchie and Williams 1998: 165; Cárcamo et al. 2001: 205.

\section{Material examined}

CANADA. British Columbia: Abbotsford, 12.vii.1950 (1 $\left.\sigma^{7}\right)$, 12.vii.1950, HP turnip (1 우, $\left.2 \sigma^{\top}\right)$, ex. C. obstrictus, JM. Aldergrove, 12.vii.1950, JM (2 우), 12.vii.1950, em. 24 (1 o $^{7}$ ), 28.vii.1950 (1 9), ex. C. obstrictus, HP turnip seed. Hatzig, 12.vii.1950, ex. C. obstrictus, GY (1 ㅇ); 12.vii.1950, ex. C. obstrictus, HP turnip (1 o , $\left.1 \sigma^{\top}\right)$. Ladner, 22.vi.1951, ex. C. obstrictus, HP turnip, KY (1 $\left.\sigma^{\top}\right)$; 29.vii.1953,

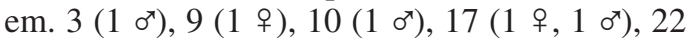
(1 + $)$, and 27.viii.1953 (1 $\left.\sigma^{\top}\right)$, ex. C. obstrictus, HP Brassica, JM. Matsqui, 12.vii.1950 (1 ㅇ), 12.vii.1950, HP Cabbage (3 o , 2 o $)$, ex. C. obstrictus, JM. Newton Station, 12.vii.1950, ex. C. obstrictus, JM (3 + $)$. Nicomen Island, 17.vii.1949, em. 10 (1 \%) and 30.viii.1949 (1 $\sigma^{7}$ ), ex. C. obstrictus, RB. Sardis, 26.vii.1949, em. $1 \quad\left(\begin{array}{ll}3 & \sigma^{\top}\end{array}\right)$ and 30.viii.1949 (1 + \%), ex. C. obstrictus, RB. Alberta: Coaldale, ca. $1 \mathrm{~km}$ $\mathrm{NE}, 49^{\circ} 44.92 \mathrm{~N}, 112^{\circ} 30.05 \mathrm{~W}, 16-30 . v i i .2002$, em. ca. 1.viii.2002, ex. B. napus pods, U\&D (4 ㅇ, $4 \mathrm{o}^{7}$ ). Lethbridge, $4 \mathrm{~km} \mathrm{SW}$, em. $c a$. 23.vii.2003, ex. B. rapa pods, U\&D (20,+ 10 $\left.\sigma^{7}\right)$. Lethbridge, 2001, dissected from S. arvensis pod (1 o ). Saskatchewan: RM108 SW15 1116 W3, 23.vii.2003, em. 812.viii.2003 (4 + , 1 ơ), RM108 SW15 1816 W3, 23.vii.2003, em. 11.viii.2003 (5 우), RM110 SW15 1116 W3, 23.vii.2003, em. 14.vii.2003 (2 +), RM110 SW26 1112 W3, 23.vii.2003, em. 6-8.vii.2003 (3 ㅇ, 2 ơ), RM142 NE28 1530 W3, 23.vii.2003, em. 12.viii.2003 (1 +), B\&O. UNITED STATES. Georgia: Spalding Co.: Bledsoe Research Farm near Griffin, winter crop without insecticide, 13.v.1996 (1 ox, UGCA), 29.v.1996 (2 ox, UGCA), 4.vi.1996 (1 +, $1 \sigma^{\star}$, UGCA), trap crop edge, 29.v.1996 (1 $\sigma^{*}$, UGCA), ex. canola seedpods, GDB. Idaho: Canyon Co.: Melba, 2 mi. N, 18.vi.1957, carrot flower, H.W. Homan (2 ㅇ, WFBM). Cassia Co.: Oakley, 27.vi.1931, no. 8, S. sophia, DEF (1 o ). Clearwater Co.: Lenore, 7.vi.1948, $1000 \mathrm{ft}$., AJW (4 ㅇ, 4 ox, WFBM). Idaho Co.: Hagerman Valley, 16.v.1929, S. filipes (1 ㅇ, WFBM). Latah Co.: 
Figs. 1-8. 1 and 2, o antenna: 1, Necremnus tidius; 2, Necremnus ? metalarus. 3 and 4, $0^{x}$ antenna with base of first flagellar segment (insert: mps, multiporous plate sensilla): 3, N. tidius; 4, Necremnus leucarthros. 5, N. tidius, + propodeum. 6-8, Mesopolobus moryoides: 6, ㅇ dorsal habitus; 7, ㅇ antenna; 8, ơ antenna. Scale bars $=100 \mu \mathrm{m}$.
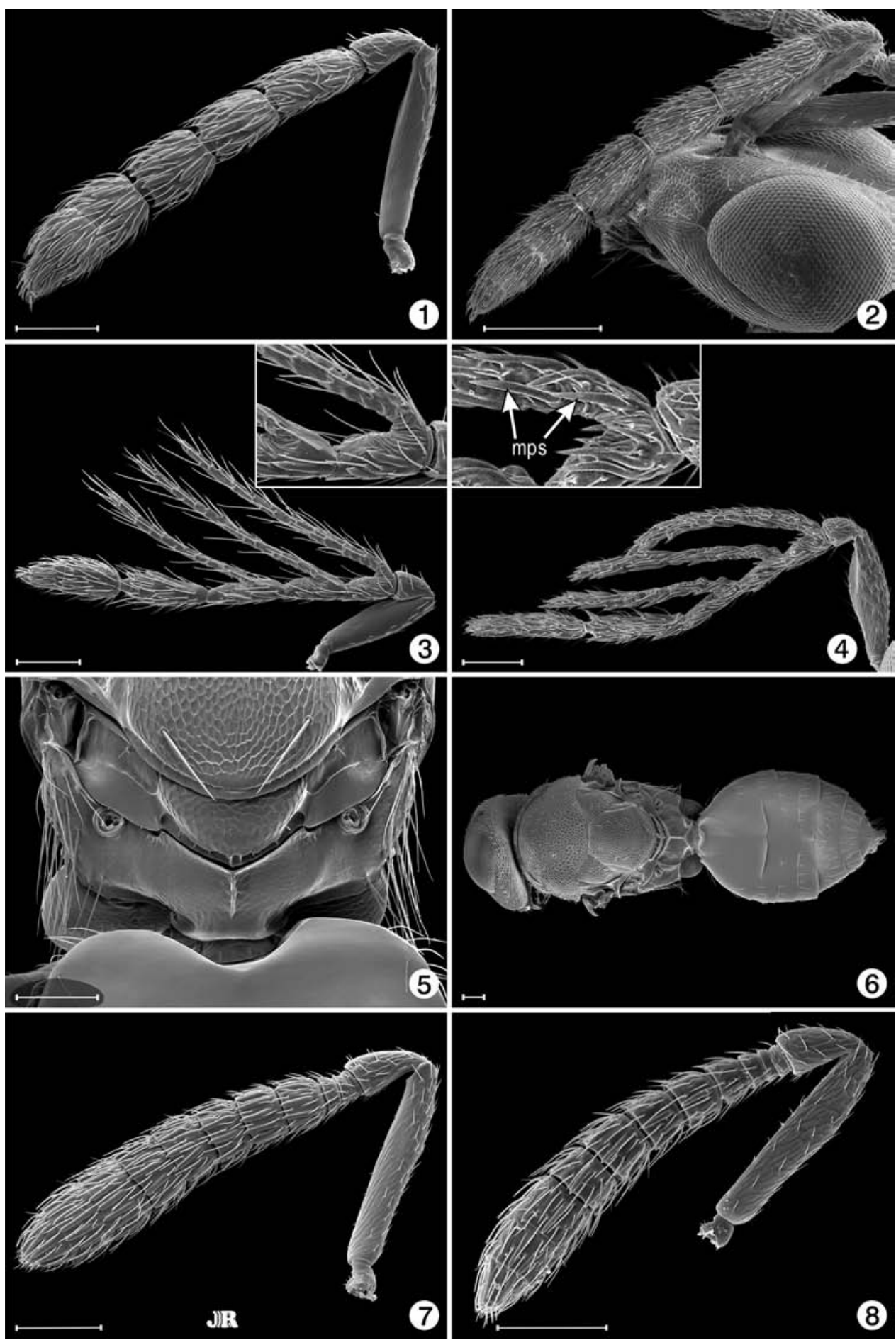

(c) 2005 Entomological Society of Canada 
Moscow, 2 mi. E, 10.vii.1988, ex. C. obstrictus, BH (1 $\left.\sigma^{\top}\right)$. Troy, 5 mi. S, 17.vii.1988, ex. C. obstrictus, BH (1 ㅇ ); 3 mi. NE, 18, 20, and 23.vii.1979, DJS (3 ㅇ, WFBM). Lewis Co.: Nezperce, 6 mi. SW, 25.vii.1979, DJS (3 ㅇ, WFBM). Nez Perce Co.: E. Lewiston Flats, vii.1947, ex. rape pod (1 우). Gifford, 11.vi.1949, 2900 ft., AJW (11 ㅇ, 3 o , WFBM). Twin Falls Co.: Castleford, 14.vi.1928, S. altissimum (1 ㅇ) , 28.vi.1928, Sophia sophia (1 $\left.\sigma^{\top}\right)$. Hollister, 24.vi.1927, S. filipes (1 우, WFBM), 24.vi.1928, S. altissimum (2 o ), 26.vi.1931, DEF (1 ơ), 16.v.1931, S. sophia, DEF (1 우), 9.vii.1932, S. parviflora, DEF (1 or, WFBM). Roseworth, 25.vi.1931, S. pestifer,

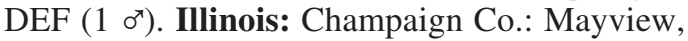
30.v.1951, ex. Ceutorhynchus sp. in Tansy mustard, D.M. Tuttle (3 ㅇ, $6 \sigma^{\top}$ ). Washington: Pierce Co.: Sumner, 30.x.1946, from pupae in seedpods, CFD (1 ㅇ). San Juan Co.: San Juan Island, viii.1945, em. pods Brassica campestris, CFD (5 ㅇ, 7 o $\left.{ }^{\top}\right)$. Skagit Co.: Laconner, 22.vii.1943, Ceutorhynchus in rutabaga seedpod, CFD (2 ㅇ). Mt. Vernon, reared 3.vii.1937, ex. C. obstrictus in turnip pod, AJH (ㅇ holotype, 19 ㅇ, $21 \sigma^{\top}$ paratypes, USNM type no. 5470; 2 ㅇ, 2 or, MTJP), 18.x.1943, in cabbage pods, ECC (1 ㅇ, MTJP).

\section{Diagnosis}

Both sexes: body comparatively dark olivegreen to blackish green with variably extensive bronze luster, at least on scutellum, under some angles of light; legs dark with knees narrowly, dorsal surface of protibia usually, and basitarsus of meso- and metatarsus white, the second tarsal segments sometimes also white but usually with at least a slight brown infusion; forewing (Fig. 29) with postmarginal vein distinctly longer than stigmal vein, speculum closed posteriorly by subcubital line of setae, and membrane entirely hyaline, including near stigmal vein. Female: flagellum (Fig. 1) with first funicular segment distinctly shorter than twice length of pedicel, second funicular segment less than twice as long as wide, and third funicular segment less than 1.5 times as long as wide; gaster less than 1.75 times as long as wide. Male: flagellum (Fig. 3) with fourth funicular segment at most about as long as clava and less than 1.5 times as long as third segment, and with first three funicular segments each having long ramus, the rami all extending to a level between base and apex of clava when appressed to flagellum, and with long, hairlike setae but without multiporous plate sensilla (in regional specimens reared from $C$. obstrictus); propodeum with median carina but otherwise smooth with very fine, meshlike sculpture, neither reticulate nor with any oblique carinae (Fig. 5).

\section{Recognition}

Gahan (1941) provided a key to the North American species of Necremnus when he described N. duplicatus, and both Bouček (1959) and Graham (1959) provided keys to the European species. Males of Necremnus are much more readily identified to species than are females. In all three of the above keys, $N$. duplicatus or $N$. tidius was keyed together with Necremnus leucarthros (Nees, 1834) and the two taxa were distinguished by structure of the flagellar sensilla. Males of $N$. leucarthros have short setae and strong, spinelike, multiporous plate sensilla (mps) on all the flagellar segments and rami (Fig. 4). Males of $N$. tidius have long, hairlike setae on the rami (Fig. 3). Furthermore, all males reared from C. obstrictus in North America that we identify as $N$. tidius do not have mps on the rami (Fig. 3) (see further below). Females of $N$. leucarthros and $N$. tidius are more difficult to differentiate. Both Bouček (1959) and Graham (1959) used colour to separate females, with those of $N$. tidius stated to be bronze or greenish bronze and those of $N$. leucarthros stated to be dark green or greenish. Necremnus females reared from $C$. obstrictus in North America and females from Europe identified as $N$. tidius (BMNH, CNC, NMBS) are comparatively dark metallic green with a variably conspicuous coppery luster at least on the scutellum, the luster sometimes restricted only to the ridges forming the interstices of the reticulations. However, some females of $N$. leucarthros from England (BMNH) and France (USNM) that are associated with males have a very similar colour, including a slight coppery luster. Gahan (1941) stated that females of $N$. leucarthros have the gaster about twice as long as wide. Females identified as $N$. leucarthros that we have seen have the gaster about 1.8-2 times as long as wide, whereas similarly preserved females of $N$. tidius, including those reared from $C$. obstrictus in North America, have the gaster only about 1.4-1.7 times as long as wide. Relative length to width ratios of the gaster can be quite variable because they are affected by whether the 
specimen is air-dried or critical-point-dried. Air-dried specimens often have the gaster strongly collapsed medially so as to be Ushaped in cross section, whereas the gaster of critical-point-dried specimens often is inflated.

Necremnus leucarthros is not known to occur in North America. Gahan (1941) noted that it had been imported from Europe and reared in Utah as a potential biological control agent of the alfalfa weevil, Hypera variabilis (Herbst, 1795) (Curculionidae), but was not known to have been released. Two other species described by Gahan (1941) that are restricted to North America, Necremnus breviramulus and Necremnus oregonensis, might also be confused with $N$. tidius because they lack forewing maculation, but females of these two species are bright metallic green without coppery luster and, like $N$. leucarthros females, have the gaster about twice as long as wide. The males of the two species are also similar to $N$. leucarthros males in flagellar sensillar structure and thus are distinguished from $N$. tidius males.

As noted above, all Necremnus males reared from $C$. obstrictus in North America that we examined did not have mps on the rami. However, either there is host-induced variation for this feature or sibling species exist within what we interpret as $N$. tidius. Two males from France and one male from Germany $(\mathrm{CNC}$, NMBS) reared from Ceutorhynchus typhae (Herbst, 1795) (= C. floralis (Paykull) vide Colonnelli, 1998) on shepherd's purse, Capsella bursa-pastoris (L.) Medik. (Brassicaceae), have mps on the apical two rami. The same flagellar structure is possessed by a male reared from the cereal stem moth, Ochsenheimeria vacculella Fischer von Röslerstamm, 1842 (Lepidoptera: Ypsolophidae), from "annual ryegrass" (Poaceae) in Oregon (Linn Co., 7.vi.1994, S. Panasahatham) (USNM). These males and those reared from $C$. obstrictus have the knees only very narrowly lightly coloured and the fourth funicular segment less than 1.5 times the length of the third segment. Females associated with the males have the first funicular segment distinctly less than twice as long as the pedicel, the second funicular segment less than twice as long as wide, and the third segment less than 1.5 times as long as wide (Fig. 1), key features used by Bouček (1959) or Graham (1959) to distinguish females of $N$. tidius and $N$. leucarthros from some other Necremnus species. Some males we have seen from Europe, reared from Lepidoptera hosts, $\mathrm{BMNH}, \mathrm{CNC}$,
WFIC) and two males from California without host data (CNC) have approximately the basal half of the meso- and metatibiae more or less white, the fourth funicular segment distinctly longer relative to the third funicular segment, and mps on all three rami (except one male from California that does not have mps on the basal ramus). Females associated with these males through label data are dissimilar to the males because their knees are only narrowly lightly coloured, as for $N$. tidius and $N$. leucarthros, but unlike females of these two species they have longer funicular segments, including having the second funicular segment twice as long as wide, the third segment more than 1.5 times as long as wide, and often the first funicular segment about twice as long as the pedicel ( $c f$. Figs. 1, 2). Furthermore, the gaster is comparatively long, similar to that described for $N$. leucarthros. These individuals undoubtedly constitute a different species from that which we identify as $N$. tidius and most likely represent a variant of Necremnus metalarus (Walker, 1839) that entirely lacks forewing maculation, as suggested for some specimens from Yugoslavia discussed by Bouček (1959). Necremnus metalarus was introduced from Europe into the western United States for biological control of the larch casebearer, Coleophora laricella (Hübner, 1817) (Lepidoptera: Coleophoridae) (Ryan et al. 1977). Some voucher specimens (WFIC) from a laboratory culture of $N$. metalarus that was established from material introduced from Austria have entirely hyaline forewings, lacking the diagnostic infuscation from around the stigmal vein, which demonstrates that this feature is variable for the species. Because those females without forewing maculation are very similar to $N$. tidius females except for slight differences in proportions of the antennal segments and gaster, it is possible that at least some of the Lepidoptera host records listed by Noyes (2002) for $N$. tidius are based on misidentifications.

\section{Hosts and biology}

Necremnus tidius is a solitary larval ectoparasitoid. In North America it has been reared definitely only from Ceutorhynchus species, including $C$. obstrictus. Specimens from Idaho (USNM, WFBM) bear label data with Sophia sophia, S. parviflora, S. filipes, S. altissimum, and S. pestifer. Sophia sophia and S. parviflora are synonyms of Descurainia sophia (L.) Webb 
(Brassicaceae), flixweed, an introduced European species that is now transcontinental in North America. S. filipes likely refers to what is now classified as Descurainia pinnata subsp. intermedia (Rydb.) Detling (Brassicaceae), western tansy mustard, which is native and restricted to western North America, whereas S. altissimum likely refers to Sisymbrium altissimum L. (Brassicaceae), tumble mustard, another introduced European species that is now transcontinental. The record of $S$. pestifer likely refers to Salsola pestifer A. Nels., a junior synonym of Salsola tragus L. (Chenopodiaceae), Russian thistle, a now transcontinental species that was introduced from Europe prior to 1900.

In Europe, Miczulski (1968) recorded $N$. tidius as a parasitoid of $C$. obstrictus in Poland, and a Necremnus species was reared from C. obstrictus in Germany (Laborius 1972), England (Nasredlin 1973; McKenna 1992), and Spain (Gomez and Zamora 1994). Kuhlmann et al. (2001) reported $N$. tidius as a parasitoid of C. typhae on C. bursa-pastoris in Germany, which was introduced to North America before 1700 and is now transcontinental (Frankton and Mulligan 1971). However, Kuhlmann et al. (2001) and Muller et al. (2004) did not rear it from $C$. obstrictus on B. napus in either Germany or Switzerland. Other host records for $N$. tidius in Europe listed by Noyes (2002) are Apion arrogans Wencker, 1858 (Curculionidae), Psylliodes marcida Illiger, 1807 and $P$. napi (Fabr., 1792) (Coleoptera: Chrysomelidae), and, as doubtful records, Argyresthia fundella (Fischer von Röslerstamm, 1835) (Lepidoptera: Yponomeutidae) (Spaic 1972), Chlorops pumilionis Bjerkander, 1778 (Diptera: Chloropidae), and Phytomyza ranunculi Schrank, 1803 (Diptera: Agromyzidae) (Bouček 1959).

\section{Distribution}

Palearctic: Canary Islands, Croatia, Czech Republic, England, France, Germany, Ireland, Israel, Netherlands, Russia, Slovakia, Spain, Sweden, Turkey, Yugoslavia (Montenegro, Serbia) (Noyes 2002). Nearctic: see Material examined; the records from Alberta, Saskatchewan, Georgia, and Illinois represent new provincial and state records. Doucette (1948) also reported $N$. tidius from Oregon (Lincoln Co., Logsden), but these specimens were not located.

\section{Remarks}

Our formal synonymy of $N$. duplicatus under $N$. tidius confirms the opinion of Bouček (1959) that the species likely were conspecific. The specimens listed above from Idaho that were collected on flixweed, tumble mustard, western tansy mustard, and Russian thistle were all collected between 1927 and 1933, prior to the known presence of $C$. obstrictus in Idaho. This may indicate that $C$. obstrictus was present in western North America earlier than the first collection records show or that $N$. tidius either is a naturally occurring Holarctic species or was introduced prior to the introduction of C. obstrictus with some other host (possibly on some non-Brassica host plant such as $C$. bursapastoris, D. sophia, or S. altissimum). Study of voucher specimens reared from canola seedpods by Buntin (1998) proves that $N$. tidius is present in Georgia, but only as a quite rare parasitoid of $C$. obstrictus. It is unknown whether its presence in the southeastern United States results from introduction with C. obstrictus from western North America or whether $N$. tidius is simply a very widely distributed species. The fact that Gahan (1941) had specimens only from Washington and Idaho when he described $N$. duplicatus probably is not significant because his revision of the genus was based only on specimens present at that time in the USNM.

\section{Mesopolobus (Xenocrepis) moryoides Gibson sp. nov.}

\author{
(Figs. 6-11, 13-15, 17, 30, 31)
}

Misidentifications. Amblymerus sp.: Doucette 1944: 124. Disema sp.: Doucette 1948: 765. Xenocrepis sp.: Hanson et al. 1948: 14. Kenocrepis sp. (lapsus for Xenocrepis): Hanson et al. 1948: 15. Xenocrepis pura Mayr: Carlson et al. 1951: 963; McLeod 1953: 13, 17; Walz 1957: 220. Xenocrepis morys (Walker): Peck 1963: 664-665 (in part). Mesopolobus morys (Walker): Burks 1979: 816 (in part); Murchie and Williams 1998: 164 (in part); Cárcamo et al. 2001: 205.

\section{Type material}

Holotype + (USNM): "[United States of America] IDAHO: Latch [lapsus for Latah] Co., Potlatch, VII-1979, ex. Ceutorhynchus assimilis". Allotype $\sigma^{\top}$ (USNM), same data as 
Figs. 9-16. 9-11, Mesopolobus moryoides 우 9, head (frontal); 10, head (lateral) and mesoscutum (dorsal); 11, lower face (oblique view). 12, Mesopolobus morys, lower face (oblique view). 13 and 14, M. moryoides: 13, ㅇ mesosoma (dorsal); 14, $\sigma^{\pi}$ mesosoma (lateral). 15 and 16, ㅇ apex of scutellum-propodeum (dorsal): 15, M. moryoides; 16, Mesopolobus trasullus. Scale bars $=100 \mu \mathrm{m}$.
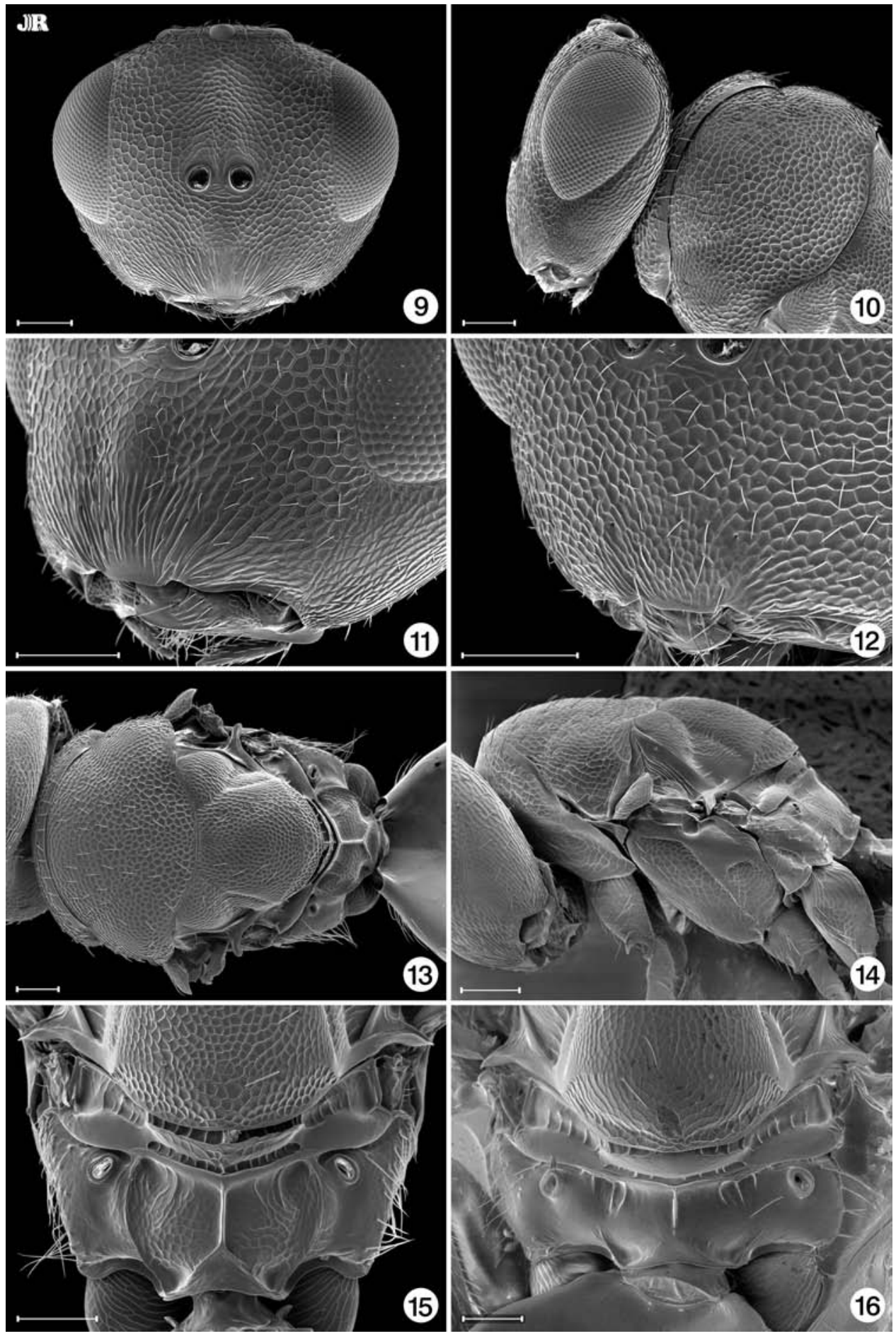

(C) 2005 Entomological Society of Canada 
holotype. Paratypes. CANADA. British Columbia: Abbotsford, 12.vii.1950, ex. C. obstrictus, JM (2 우). Aldergrove, 12.vii.1950, ex. C. obstrictus, HP turnip (1 우). Creston, 17.vi.2001, canola sweep sample, AF (5 우). Ladner, 29.vii.1953 (8 우), em. 927.viii.1953 (7 ㅇ, 5 o $)$, HP Brassica, JM; 26.vii.1954, em. 16.viii.1954, HP Brassica, JM (3 ㅇ). Matsqui, 12.vii.1950, HP turnip (2 ㅇ), 12.vii.1950, JM (3 ㅇ), ex. C. obstrictus. Newton Station, 12.vii.1950, HP turnip (1 o ). Nicomen Island, 3.viii.1951, ex. C. obstrictus, HP wild mustard, GY (5 ㅇ, $\left.2 \sigma^{\pi}\right)$. Sardis, 26.vii.1949, em. 19.viii.1949, ex. C. obstrictus, $\mathrm{HP}$ wild mustard/turnip seed, $\mathrm{RB}$ (3 우); 12.vii.1950, em. 28.vii.1950 (1 $\left.\sigma^{\top}\right)$, em. 26.viii.1950 (1 우), ex. C. obstrictus, HP turnip seed. Vancouver, University of British Columbia, 12.vii.1950, em. 26.vii.1950, ex. C. obstrictus, HP turnip seed (1 우). UNITED STATES. California: Alameda Co.: Berkeley, 14.vii.1950, ex. C. obstrictus, RLD (3 ㅇ). San Joaquin Co.: Thornton, 7.vi.1951, mustard, ECC (12 ㅇ, 4 ๙ , UCDC). San Mateo Co.: Half Moon Bay, 13.vii.1950, ECC (1 +, CNC). Pescadaro, 5 (1 우, 1 ㅈ), 6 (1 우), and 9.viii.1950 (1 우, $1 \sigma^{\pi}$ ), WHL. Georgia: Spalding Co.: Bledsoe Research Farm near Griffin, winter crop without insecticide, 1.v.1995 (1 o $\sigma^{\pi}$, UGCA), trap crop center, 29.v.1996 (1 우, UGCA), ex. canola seedpods, GDB. Idaho: Clearwater Co.: Lenore, vii.1947, rape pod, CFD (10 ㅇ, 4 ơ); 7.vi.1948, ex. C. obstrictus on rape seed, AJW (2 ㅇ, 1 ơ); 7.vi.1948, 1000

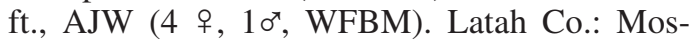
cow, viii.1946, turnip pods, CFD (5 ㅇ, $\left.1 \sigma^{\top}\right)$. Potlach, vii.1979, ex. C. obstrictus (4 ㅇ, $\left.5 \sigma^{\top}\right) ; 2$ mi. NW, 18, 20, 23, 25, 26, 30, and 31.vii.1979, DJS (57 ㅇ, 7 ๙ ๙ $^{\pi}$ WFBM). Troy, 3 mi. NE, 25, 30.vii.1979, DJS (1 ㅇ, 1 \%, WFBM). Lewis Co.: Nezperce, 30.vii.1979, HWH.20.79, A. Ahmad (1 ㅇ, $2 \sigma^{x}$, WFBM); 6 mi. SW, 26, 30, and 31.vii.1979, 1.viii.1979, DJS (18 ㅇ, $1 \sigma^{x}$, WFBM). Nez Perce Co.: E. Lewiston Flats, vii.1947, ex. rape pods, CFD (E) (1 o ). Gifford, 7, 11.vi.1949, 2900 ft., ex. C. obstrictus, AJW (10 우, 15 ๙, WFBM). Illinois: Champaign Co.: Mayview, 30.v.1951, ex. Ceutorhynchus sp. in Tansy mustard seed, D.M. Tuttle (2 o, $\left.1 \sigma^{r}\right)$. Oregon: Benton Co.: Corvallis, 10, 13.vii.1951, ex. weevil grub on turnip and cabbage, H.H. Crowell (2 우, OSAC). Marion Co.: Salem, 8 mi. E, 20.vi.1968, ex. Brassicaceae (2 ㅇ, 2 o , OSAC). Washington: Pierce Co.: Sumner, 6.vii.1943,
C. obstrictus larva, CFD (1 o ); 9.vii.1945, rutabaga pods, CFD (6 + ); 12.vi.1946, pods crucifers, CFD (4 + ). San Juan Co.: San Juan Island, viii.1945, ex. pods Brassica campestris, CFD (24 ㅇ, 16 ๙ $)$. Skagit Co.: Mount Vernon, 3.vii.1936, ex. C. obstrictus, AJH (3 우, 1 o'); reared 3.vii.1937, ex. C. obstrictus in turnip pod, AJH (12 ㅇ, 29 o'; 2 우, 2 o', MTJP).

\section{Etymology}

The name moryoides is formed from the species name morys and the suffix oides, meaning "resembling", in reference to the distinctively widened marginal vein shared by males of the two species.

\section{Diagnosis}

Both sexes: tegula dark, not contrasting in colour with rest of mesosoma; legs with trochanters and femora extensively dark; clypeus strigose (Fig. 11); pronotum rounded dorsally, without transverse carina distinguishing collar from neck (Figs. 10, 14); propodeum with distinct meshlike sculpture medially between spiracles (Figs. 15, 17); forewing with basal fold bare dorsally (Figs. 30, 31). Male: marginal vein conspicuously widened (Fig. 31); gaster dark without yellow spot dorsally.

\section{Description}

Holotype female. Length: $2.3 \mathrm{~mm}$. Head dull metallic green; palpi brown; scape yellow to slightly brown dorsoapically, pedicel and flagellum more distinctly brown, but funicle and clava with white mps. Head (Figs. 9, 10) width : height : length, 9.6:7.3:3.5; eye height : eye width : length of malar space : width of oral cavity, 4.4:3.3:2.1:4.3; OOL : LOL : POL : maximum diameter of anterior ocellus, 1.2:1.2:2.6:0.8; minimum distance between eyes dorsally, 5.8. Face reticulate; clypeus strigose, the anterior margin truncate (Figs. 9, 11). Antenna inserted above imaginary line drawn between lower orbits (Fig. 9), with ventral margin of torulus about 1.4 times farther from anterior ocellus than from anterior margin of clypeus. Antennal formula $1: 1: 3: 5: 3$, but clava with small, circular, terminal micropilose region superficially appearing as fourth claval segment; scape not quite extending to ventral margin of anterior ocellus, its length excluding radicle about 0.75 times eye height; pedicel twice as long as wide, its apical width slightly greater than combined length of three strongly transverse anelli but less than width of 
flagellum; funicular segments transverse, each with dense row of mps, the sensilla somewhat more widely separated on basal segments but most sensilla separated by distance similar to or less than width of sensillum (Fig. 7); clava 1.7 times as long as wide and equal in length to apical three funicular segments; combined length of flagellum and pedicel about 0.75 times head width.

Mesosoma dull metallic green with slight bronze luster on mesonotum under some angles of light, about 1.4 times as long as wide; tegula not contrasting distinctly in colour with mesosoma, with slight metallic luster basally but brownish hyaline over about apical half. Pronotum rounded anteriorly, without transverse carina differentiating collar from neck (Figs. 10, 14), in dorsal view very short, only about 0.08 times as long as mesoscutum (Fig. 13). Mesonotum (Fig. 13) reticulate, the reticulations only slightly smaller on scutellum than on mesoscutum; mesoscutum about 1.6 times as wide as long and with obscure, scattered, tiny setiferous punctures anteriorly; scutellum slightly longer than wide, with frenum obscurely differentiated at level of posterior paralateral setae. Dorsellum reticulatecoriaceous (Fig. 15). Propodeum (Fig. 15) with complete plical furrows differentiating distinct median area, the outer margin of each plical furrow carinate posterior to about level of posterior margin of spiracle; median area about twice as wide as long, distinctly reticulate with line of crenulae along anterior margin and anterolateral fovea, and with an inverted Yshaped carinal complex formed by complete median carina and carinately margined adpetiolar strip; callus setose only lateral to spiracle, with region between postspiracular furrow and plical furrow distinctly sculptured, similar to that of median area. Forewing (Fig. 30) hyaline, venation whitish yellow; costal cell ventrally with line of anterior setae widely spaced medially; basal cell, basal fold, and mediocubital fold bare; speculum narrowed to juncture of marginal and stigmal veins; relative length of costal cell : marginal vein : stigmal vein : postmarginal vein = 9.1:4.4:3.1:4.4. Legs with coxae, trochanters, and all but extreme apices of femora dark with slight metallic luster; trochantelli, apices of femora, tibiae, and basal four tarsal segments yellowish white, but meso- and metatibiae extensively light brown medially and apical tarsal segment darker brown.

Gaster broadly ovate, about 1.3 times as long as wide and subequal in length to mesosoma (Fig. 6); $\mathrm{Gt}_{1}$ smooth, shiny, with metallic green to blue luster except for coppery brown posterior margin; $\mathrm{Gt}_{2}-\mathrm{Gt}_{4}$ mostly coppery brown dorsally but with progressively larger anterolateral metallic regions of similar luster as on $\mathrm{Gt}_{1} ; \mathrm{Gt}_{5}$ to syntergum with metallic luster similar to that of $\mathrm{Gt}_{1} ; \mathrm{Gt}_{2}$ to syntergum finely coriaceous except posterior margins of $\mathrm{Gt}_{2}-\mathrm{Gt}_{4}$ broadly smooth; $\mathrm{Gt}_{2}$ and $\mathrm{Gt}_{3}$ with setal line laterally, $\mathrm{Gt}_{4}$ and $\mathrm{Gt}_{5}$ with complete line of setae across terga, $\mathrm{Gt}_{6}$ with two lines of setae, and syntergum with line of setae between cerci; hypopygium apex extending to about 0.55 times length of gaster.

Allotype male. Length: $1.9 \mathrm{~mm}$. Similar to female except as follows: antenna (Fig. 8) with ventral surface of pedicel and flagellum yellow, scape extending to anterior ocellus, and mps sparser, separated by at least twice width of sensillum; head width : height : length, 7.8:6.2:3.4; eye height : eye width : length of malar space : width of oral fossa, 3.5:2.8:1.9:4.1; OOL : LOL : POL : maximum diameter of anterior ocellus, 1.0:1.0:2.3:0.6; minimum distance between eyes dorsally, 4.9; combined length of pedicel and flagellum about 0.85 times head width; propodeum distinctly sculptured medially between spiracles but median area less distinctly differentiated by shallower plical furrows (Fig. 17); forewing (Fig. 31) with speculum distinct only to about middle of marginal vein, relative length of costal cell : marginal vein : stigmal vein : postmarginal vein $=6.8: 3.5: 2.7: 3.8$, the marginal vein conspicuously thickened, slightly convex with posterior margin very slightly curved, about 5 times as long as greatest width, and yellow similar to rest of venation; legs with tibiae yellowish white; gaster more extensively brown dorsally, about 1.75 times as long as wide and about 1.2 times as long as mesosoma.

\section{Variation}

The primary types appear to be air-dried; critical-point-dried specimens can have the gaster inflated so that in females it is more lanceolate and longer, up to about 1.5 times as long as wide and 1.3 times as long as the mesosoma. Intensity of colour can vary such that females sometimes have the tibiae entirely yellow and other times extensively dark with a 
slight metallic luster medially, and both sexes sometimes have darker venation, brown in males. The costal setal line may or may not be distinctly interrupted medially, but at least the setae are always conspicuously more widely spaced medially. None of the females have setae on the dorsal surface of the basal fold (Fig. 30), though sometimes there is a single seta on the ventral surface near the parastigma. Males have up to 3 setae on or near the basal fold, comprising some combination of 1-3 setae on the dorsal surface and 1-3 setae on the ventral surface of the wing (Fig. 31). Males also sometimes do not have the ventral line of costal setae distinctly interrupted medially.

\section{Differentiation}

Mesopolobus moryoides is assigned to the subgenus Xenocrepis, which is differentiated from other recognized subgenera of Mesopolobus primarily by the absence of a pronotal carina (Figs. 10, 14) and the head being comparatively thin in lateral view (Fig. 10), as described in the key by Bouček and Rasplus (1991). It is the fourth species to be classified in $M$. (Xenocrepis), along with $M$. morys, M. incultus (Walker, 1834), and M. trasullus (Walker, 1839).

Gibson and Baur (2005) provided features to differentiate the latter two species after resurrecting $M$. trasullus from synonymy with $M$. incultus and treating it as the senior synonym of $M$. roseni Graham (1984). Females of $M$. moryoides are most similar to those of $M$. trasullus because they share a strigose clypeus (Fig. 11) and a dark tegula and have the ventral line of costal setae interrupted medially, or at least the setae are somewhat more widely spaced medially. Females of $M$. morys and $M$. incultus differ from the other two species in having a reticulate clypeus (Fig. 12), the tegula yellow over at least the basal two thirds, and an evenly spaced line of ventral costal setae. Sculpture of the propodeum most readily differentiates females of $M$. moryoides from those of M. trasullus. The latter have the propodeum quite smooth and shiny with an indistinct median area because of the absence of plical carinae or furrows (Fig. 16), whereas females of M. moryoides (Fig. 15) have a distinctly delineated and sculptured median propodeal area, the propodeum being more similar to that of $M$. morys females. Females of M. trasullus also have at least two and often several setae on the dorsal surface of the basal fold ( $c f$. Fig. 32), and a longer and more distinctly lanceolate gaster and a shorter pedicel than M. moryoides females. Males of $M$. moryoides are superficially most similar to $M$. morys males because of their expanded marginal vein (cf. Figs. 31, 32 ). It is because of this distinctive venational feature, previously thought to be unique to males of M. morys within Mesopolobus, that the species reared from $C$. obstrictus in North America was misidentified previously. Males of $M$. moryoides are readily separated from those of $M$. morys by their entirely dark tegula and dark palpi, largely dark femora, and strigose clypeus.

\section{Hosts and biology}

Mesopolobus moryoides is a solitary ectoparasitoid of $C$. obstrictus and possibly other Ceutorhynchus species, as indicated by the record from Illinois, from where C. obstrictus is not yet recorded.

\section{Distribution}

Known only from North America.

\section{Remarks}

Only a single male and female of M. moryoides were found among 1124 voucher specimens of chalcids reared over 3 years from canola seedpods by Buntin (1998). His study verifies the presence of $M$. moryoides in Georgia but indicates that this species is a much rarer parasitoid of $C$. obstrictus in the southeastern United States than in the northwestern United States and western Canada. Specimens collected in Illinois suggest that the species has a much wider distribution than presently documented by collection records.

Because $M$. moryoides is known only from North America, it may be a native species that expanded its host range to include $C$. obstrictus after this species was introduced. If so, its native host is likely noneconomic and comparatively rare because we have not seen $M$. moryoides in any collection made prior to its being reared from $C$. obstrictus almost immediately after this species was discovered in Washington (Baker 1936). The timing and host association suggest the alternative possibility that $M$. moryoides is an introduced species from Europe. If so, it likely remains unrecognized in Europe within $M$. morys because of the similarly enlarged marginal vein of males, and 
probably is quite rare or has a very restricted distribution.

\section{Trichomalus lucidus (Walker)}

(Figs. 18-21, 23, 25, 26, 33, 35)

Pteromalus lucidus Walker, 1835: 484. Lectotype ㅇ (BMNH, examined) designated by Graham 1956: 248.

Pteromalus brevicornis Walker, 1835: 491. Lectotype o $(\mathrm{BMNH})$ designated by Graham 1956: 248; synonymy by Graham 1956: 248.

Pteromalus chalceus Walker, 1835: 491. Lectotype o (BMNH) designated by Graham 1956: 248; synonymy by Graham 1956: 248.

Pteromalus despectus Walker, 1835: 491. Lectotype o (BMNH) designated by Graham 1956: 248; synonymy by Graham 1956: 248.

Pteromalus rusticus Walker, 1836: 482. Syntype o (BMNH); synonymy by Graham 1956: 248.

Pteromalus mundus Förster, 1841: 12. Lectotype o (NMWA) designated by Graham 1969: 726; synonymy by Delucchi and Graham 1956: 572.

Pteromalus lyttus Walker, 1848: 194. Lectotype o $(\mathrm{BMNH})$ designated by Graham 1956: 248; synonymy by Graham 1956: 248.

Isocyrtus (Trichomalus) fasciatus Thomson, 1878: 139. Lectotype o (MZLU) designated by Graham 1969: 726; synonymy by Graham 1956: 248.

Pteromalus purus Dalla Torre, 1898: 144. Replacement name for P. mundus Förster, 1841, preoccupied by $P$. mundus Walker, 1836 .

Trichomalus fasciatus Breakey et al. 1944: 118; Doucette 1944: 124; Doucette 1948: 764, 765; Hanson et al. 1948: 14, 15; Baird 1949: 276, 278; Carlson et al. 1950: 390; Carlson et al. 1951: 964; McLeod 1951: 35; Crowell 1952: 546; McLeod 1953: 13-16; Walz 1957: 219; McLeod 1962: 6.

Trichomalus perfectus Peck 1963: 669; Murchie and Williams 1998: 164; Cárcamo et al. 2001: 205; Kuhlmann et al. 2002: 55.

\section{Material examined}

CANADA. British Columbia: Agassiz, 22.vii.1939, ex. C. obstrictus, RG (2 ㅇ, $\left.3 \sigma^{\top}\right)$. Chilliwack, em. 3.ix.1943, ex. C. obstrictus (2 +). Creston, 17.vi.2001, canola sweep sample, $\mathrm{AF}\left(3\right.$ ㅇ, $\left.10^{\top}\right)$. Dewdney, 27.vi.1934 (1 ; 2 우, USNM), 22.vii.1939 (43 우 5 or), ex. C. obstrictus, RG. Fraser valley, vi.1951, ex.
C. obstrictus, HP turnip, JM (29 우 28 o $\left.{ }^{7}\right)$. Ladner, 14.vii.1949, em. 13.viii.1949, RB (1 +), 29.vii.1953, em. 3-24.viii.1953, JM (2 ㅇ, 3 $\left.{ }^{7}\right)$, ex. C. obstrictus; 29.vii.1953, ex. C. obstrictus, HP Brassica, JM (3 $\left.\sigma^{7}\right)$. Nicomen Island, 3.viii.1951, ex. C. obstrictus, HP wild mustard, GY $\left(2 o^{7}\right)$. Sardis, 26.vii.1949, ex. C. obstrictus, HP Brassica, RB (1 ㅇ, $\left.10^{7}\right)$. Vancouver, 23.viii.1951, em. 29.viii.1951, ex. C. obstrictus (3 $\left.0^{7}\right)$; University of British Columbia, 11.vii.1950, em. 24.vii.1950 (1 $\left.\sigma^{\top}\right)$, 17.vii.1949, em. 19.viii.1949, RB (1 우 2 ơ), ex. C. obstrictus, HP Brassica. Vancouver Island, 2.viii.1949, em. 19-29.viii.1949 (2 우), 10.vii.1951, em. 23.viii.1951 (1 o). Alberta: Bow Island, $c a .8 \mathrm{~km} \mathrm{SE}$, em. ca. 18.vii.2003, ex. B. rapa pods, U\&D $\left(2 \sigma^{7}\right)$. Coaldale, $c a$. $1 \mathrm{~km} \quad \mathrm{NE}, \quad 49^{\circ} 44.92 \mathrm{~N}, 112^{\circ} 30.50 \mathrm{~W}, 16-$ 30.vii.2002, em. ca. 1.viii.2002, ex. B. napus pods, U\&D (5 ㅇ, 3 o $^{7}$ ). Lethbridge, 4.vi.2001, canola sweep sample, AF (1 ㅇ); $c a .4 \mathrm{~km} \mathrm{SW}$, em. ca. 12.viii.2003, ex. B. napus pods, U\&D $\left(10\right.$ i, $\left.10 \sigma^{r}\right)$. UNITED STATES. Idaho: Clearwater Co.: Lenore, vii.1947, C. obstrictus in rape seedpods, CFD (2 +, $\left.10^{\top}\right)$; 7.vi.1948, ex. C. obstrictus in rape seedpods, AJW (1 o, 1 $\left.{ }^{7}\right)$; 7.vi.1948, $1000 \mathrm{ft}$., AJW (5 우, WFBM). Latah Co.: Potlach, 2 mi. NW, 23, 25, 30, and 31.vii.1979, DJS (5 ․, $20^{x}$, WFBM). Troy, 3 mi. NE, 23 and 30.vii.1979, DJS (5 ㅇ, $10^{\pi}$, WFBM). Nez Perce Co.: Gifford, 11.vi.1949, 2900 ft., ex. C. obstrictus, AJW (18 ㅇ, 8 o, WFBM). Oregon: Benton Co.: Corvallis, 10.vii.1951, ex. C. obstrictus, H.H. Crowell (1 o, $\left.1 o^{\top}\right) ; 6,10,13,16$, and 23.vii.1951, ex. weevil grub on turnip and cabbage, H.H. Crowell (10 ㅇ, $40^{\pi}$, OSAC). Marion Co.: Salem, 8 mi. E, 20.vi.1968, ex. Brassicaceae (9 우 2 o", OSAC). Washington: Pierce Co.: Sumner, from pupae in seedpods (1 \%); 22.vii.1943, ex. C. obstrictus larva in rutabaga seedpods, CFD (6 ㅇ, $1 \sigma^{\top}$ ); vii.1944, rutabaga pods, CFD (1 ㅇ, 9 ơ); vii.1945, em. pods B. campestris, CFD (6 ㅇ); 17.vi.1946, pods crucifers, CFD (6 ㅇ); vii.1947, ex. C. obstrictus on cabbage, CFD (1

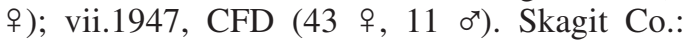
Mount Vernon, 3.vii.1936, ex. C. obstrictus, AJH (12 +), reared 3.vii.1937, ex. C. obstrictus in turnip pod, AJH (17 ㅇ, 21 or $^{x} 2$ ㅇ, $2 \sigma^{x}$, MTJP); 18.x.1943, in cabbage pods, ECC (3 우, $4 \mathrm{o}^{x}$, MTJP); 3 mi. S, 19.iv.1946, on turnip, ECC (3 ㅇ, UCDC). Sweeping cabbage seed stalks, 15.vii.1943, 30.vi.1944, ECC (2 o, UCDC). Snohomish Co.: Stanwood, sweeping 
Figs. 17-24. 17, Mesopolobus moryoides, ơ propodeum (dorsal). 18-20, Trichomalus lucidus: 18, ㅇ head and pronotum (dorsal); 19, ㅇ antenna; 20, o* antenna. 21 and 22, ㅇ metacoxa (lateral): 21, T. lucidus; 22, Trichomalus perfectus. 23 and 24, $\sigma^{x}$ propodeum and metacoxa (dorsal): 23, T. lucidus; 24, T. perfectus. Scale bars $=100 \mu \mathrm{m}$.
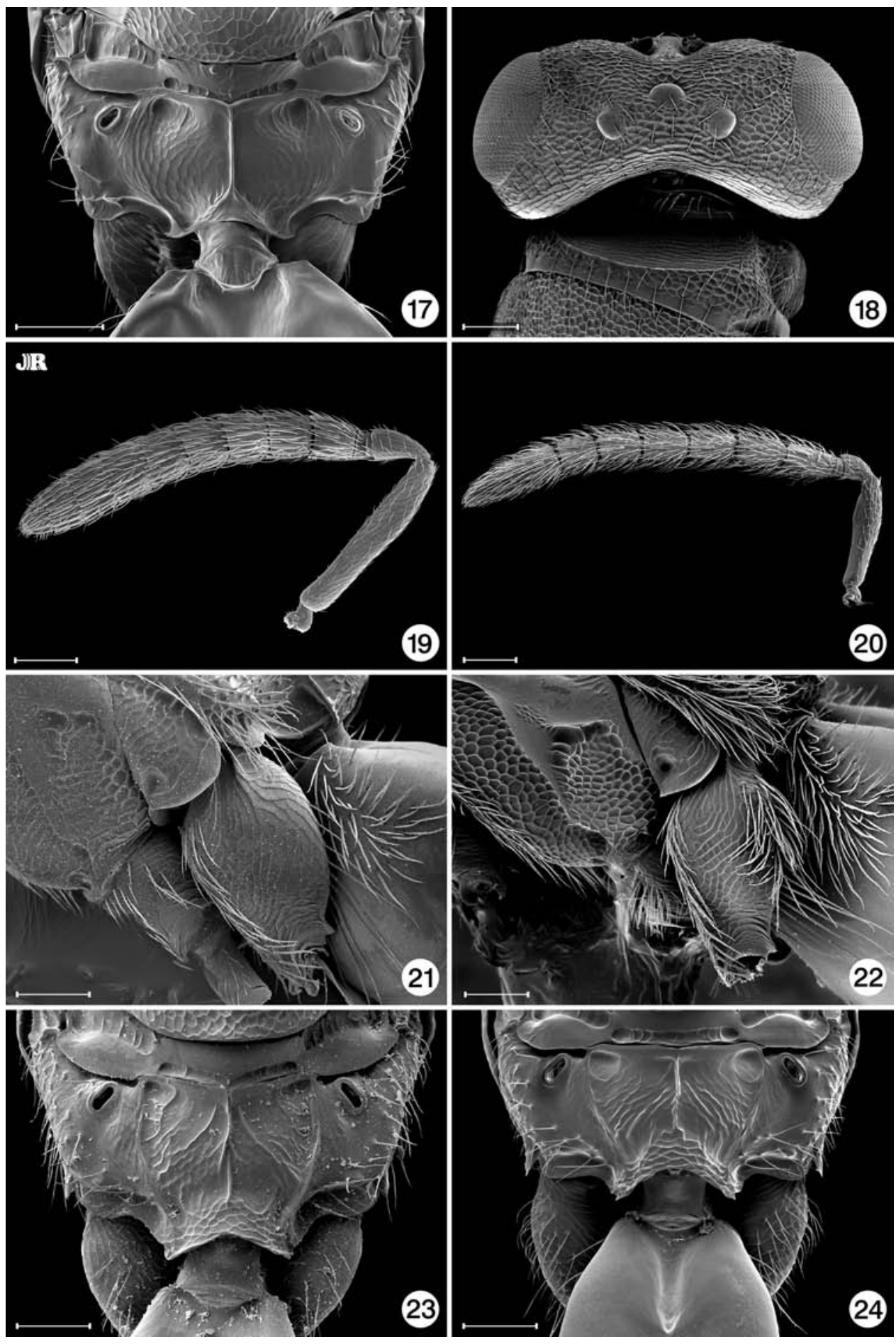

(C) 2005 Entomological Society of Canada 
Figs. 25-28. ㅇ propodeum: 25, Trichomalus lucidus (dorsal); 26, T. lucidus (oblique view); 27, Trichomalus perfectus (dorsal); 28, Trichomalus bracteatus (dorsal). Scale bars $=100 \mu \mathrm{m}$.
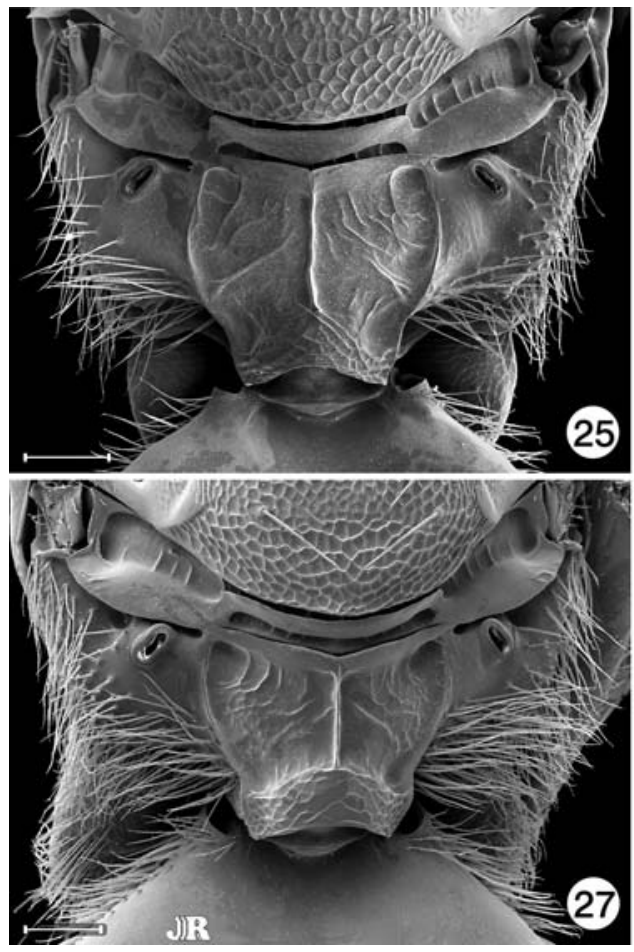

cabbage seed stalks and rye, 17.vii.1944, ECC (1 ㅇ, UCDC).

\section{Diagnosis (based on North American specimens)}

Female: head and body metallic green with tegula and scape yellow except scape sometimes dark apically; legs beyond coxae with apical tarsal segments dark, but otherwise more or less yellow to orange, with femora sometimes partly brown to dark brown or with some metallic luster and tibiae rarely light brown, but then at least knees and tibiae apically lighter yellow to white. Head in dorsal view about 2.12.25 times as wide as long (Fig. 18). Antenna (Fig. 19) with flagellum distinctly wider than apical width of pedicel; funicular segments with single row of dense mps. Forewing (Fig. 33) with marginal vein about $1.65-1.8$ times as long as stigmal vein; basal cell usually bare but at most with 1 or 2 setae very near basal fold, the basal fold with at least 1 and usually 4-9 setae, and mediocubital fold usually without or with 1 , rarely 2 setae, but with a combined maximum total of 11 setae. Legs with metacoxa comparatively sparsely setose dorsally (Fig. 21). Propodeum (Figs. 25, 26) with plical

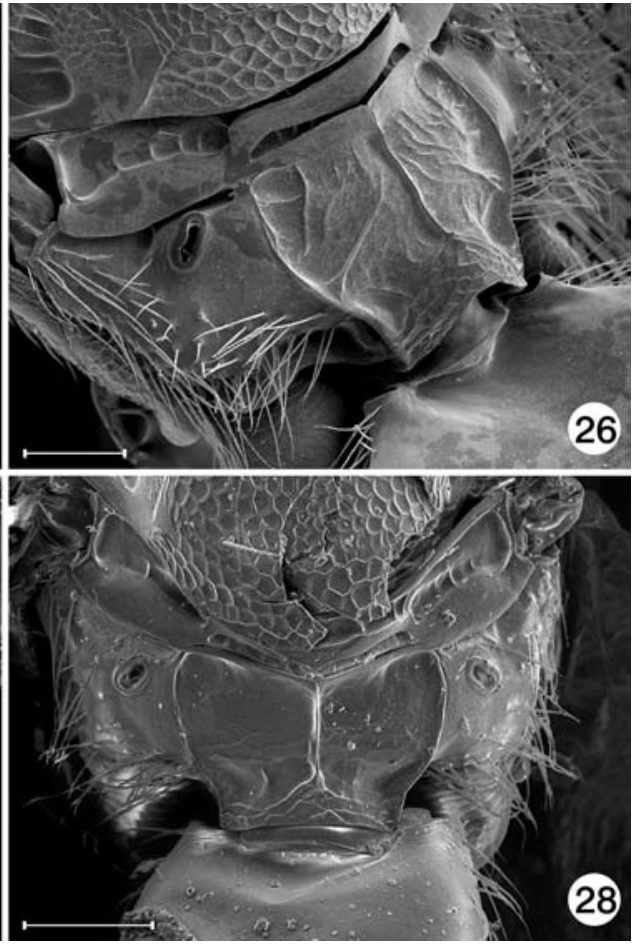

region about 1.2-1.4 times as wide as medial length of propodeum, delineated by strong, complete plical carinae, with median carina, and usually with more or less complete oblique costula medially; callus dorsally with more or less triangular bare region extending posteriorly to nucha lateral to plical carina (Fig. 25), the setal tubercles of setose region visible only laterally or extending from side and attenuating to point near intersection of plical carina and nucha (Figs. 25, 26); nucha weakly reticulate. Gaster about 1.75 times as long as wide; subequal in length to, or in air-dried specimens even slightly shorter than, combined length of head and mesosoma. Male: similar to female except scape and legs beyond coxae entirely yellow, gaster with subbasal yellow spot; flagellum (Fig. 20) filiform with sparse mps in single row over about apical half of all but apical segment, and with first funicular segment conspicuously longer than pedicel and at least equal in length to second funicular segment; forewing (Fig. 35) with marginal vein about 1.55-1.9 times length of stigmal vein, basal cell sometimes with 1 or 2 setae within cell apically and often closed posteroapically by up to 3 setae, and basal fold with 4-8 setae on dorsal 
Figs. 29-32. Forewing: 29, Necremnus tidius, ㅇ; 30, Mesopolobus moryoides, ㅇ; 31, M. moryoides, ơ; 32, Mesopolobus morys, ${ }^{\star}$. Scale bars $=0.5 \mathrm{~mm}$.

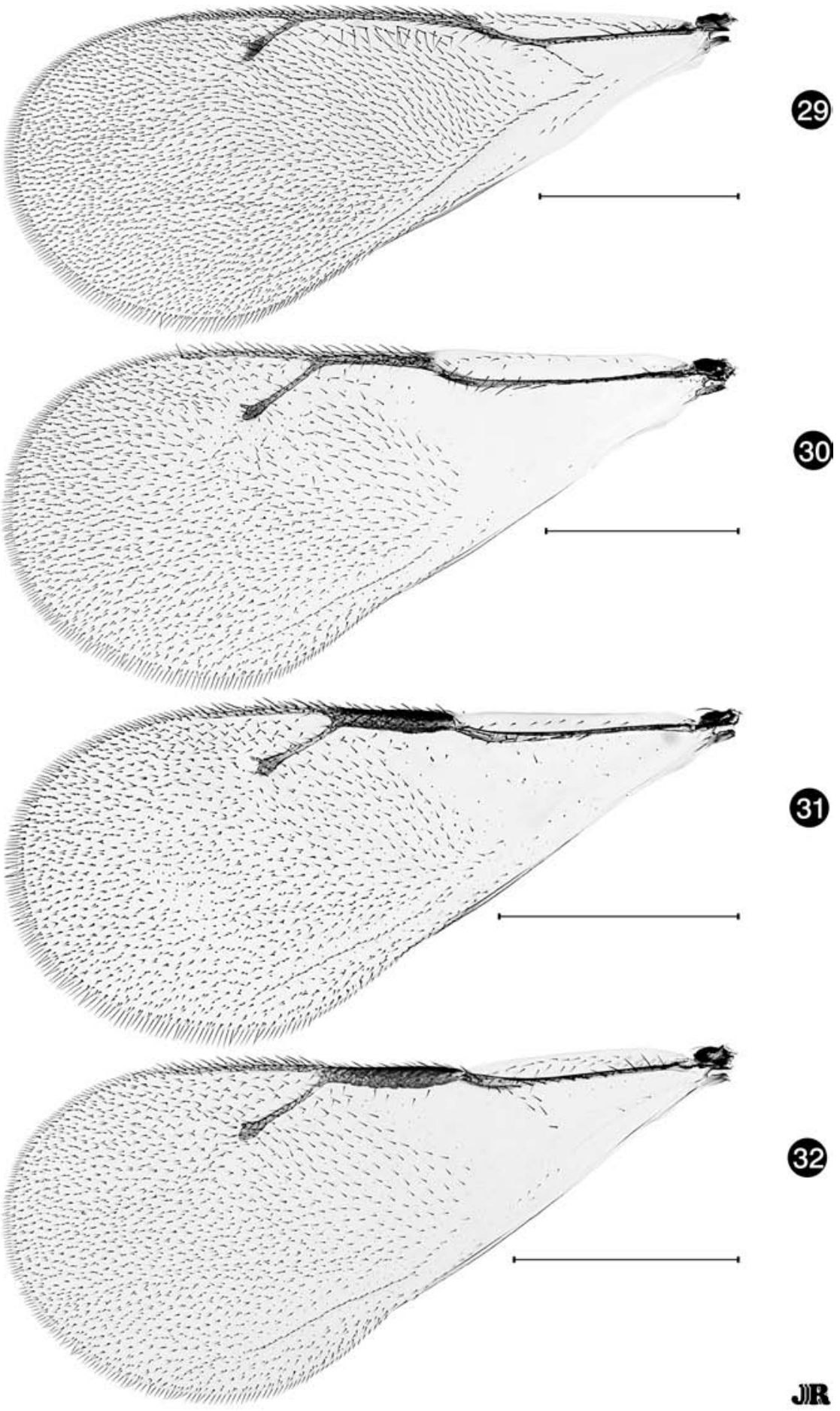


surface and 1 or 2 setae on ventral surface toward parastigma; propodeum (Fig. 23) almost half as long as scutellum, with nucha weakly aciculate.

\section{Recognition}

Trichomalus lucidus is distinguished from T. perfectus by three principal differences. Although metacoxal setation is somewhat variable and Figures 21 and 22 illustrate opposite extremes for females of the two species, the metacoxae are less densely setose dorsally in both sexes of T. lucidus (Figs. 21, 23) than they are in T. perfectus (Figs. 22, 24). Both sexes of T. lucidus also have a longer marginal vein relative to the stigmal vein than does $T$. perfectus. Based on North American specimens of T. lucidus, females have the marginal vein about 1.65-1.85 times the length of the stigmal vein (Fig. 33), compared with about 1.4-1.6 times for $T$. perfectus (Fig. 34). Males of T. lucidus have the marginal vein about 1.55 1.9 times the length of the stigmal vein (Fig. 35), compared with about 1.3-1.45 times for T. perfectus (Fig. 36). Females of the two species also have a different propodeal setal pattern lateral to the plical carina. In T. perfectus, there is a more or less quadrate bare region anteriorly and a transverse setose region posteriorly (Fig. 27), with the setae originating from distinct tubercles that extend in a broad band over the callus to the plical carina distinctly anterior to the nucha. Females of T. lucidus have a more triangular bare region because it extends along the plical carina to the nucha (Fig. 25) or, if the setae extend somewhat anterior to the nucha, then the setal tubercles are visible only laterally or attenuate to a point near the intersection of the plical carina and nucha (Fig. 26). The difference in setal pattern is not so conspicuous for males of the two species (Figs. 23, 24). Females of both T. lucidus and $T$. perfectus have a comparatively long propodeum (Figs. 25, 27), which differentiates them from females of Trichomalus bracteatus (Walker, 1835) (Fig. 28).

\section{Hosts and biology}

Trichomalus lucidus is a solitary larval ectoparasitoid. In North America it has been reared only from $C$. obstrictus. In Europe, Kuhlmann et al. (2000) reared it from the larvae of Ceutorhynchus pallidactylus (Marsham, 1802) on cabbage, Brassica oleracea L., in
Switzerland and from $C$. alliariae in the stems of garlic mustard, Alliaria petiolata (Bieb.) Cavara \& Grande (Brassicaceae), in northern Germany. Garlic mustard was introduced from Europe to eastern North America before 1900 and now extends to the west coast. Klander (2001) reported that T. lucidus comprised $8 \%$ of the ectoparasitoids reared from $C$. obstrictus on canola in northern Germany and that it parasitized $C$. alliariae and $C$. roberti on garlic mustard. Muller et al. (2003) also reported it as a parasitoid of the latter two Ceutorhynchus hosts in surveys conducted in Switzerland in 2001, and from Ceutorhynchus scrobicollis Nerensheimer et Wagner, 1924 on garlic mustard in Germany, but not from $C$. obstrictus on canola in Germany. Muller et al. (2004) also did not recover it as a parasitoid of C. obstrictus in 2002 surveys in either Germany or Switzerland, though they did recover it in Germany from $C$. alliariae and $C$. roberti on garlic mustard and from Microplontus rugulosus (Herbst, 1795) (Curculionidae) on German chamomile, Matricaria recutita L., and scentless chamomile, Tripleurospermum perforatum (Merat) (Asteraceae).

\section{Distribution}

Palearctic: Germany, Ireland, Spain, Sweden, Switzerland, United Kingdom (England, Scotland) (Noyes 2002). Nearctic: see Material examined; the records from Alberta represent a new provincial record. Carlson et al. (1951) also reported a single female from California (San Joaquin Co., Thornton area), which was not located.

\section{Remarks}

The earliest identifications of this species in North America as T. fasciatus (Thomson, 1878) (nec Förster, 1841) were made by A.B. Gahan of the USNM, as first acknowledged in Hanson et al. (1948). Although Graham (1956) later synonymized $T$. fasciatus with $T$. lucidus, Gahan's original identification has proven correct relative to more recent identifications of the species as $T$. perfectus. The accuracy of Gahan's identification is quite remarkable because at the time both the European and the Nearctic species of Trichomalus were unrevised, without keys to species. Gahan's ability to correctly identify the species apparently resulted from a 1927 trip to major European museums to study type material (Cory and 
Figs. 33-36. Forewing: 33, Trichomalus lucidus, ㅇ; 34, Trichomalus perfectus, ㅇ; 35, T. lucidus, ơ; 36, T. perfectus, $\sigma^{\pi}$. Scale bars $=0.5 \mathrm{~mm}$.

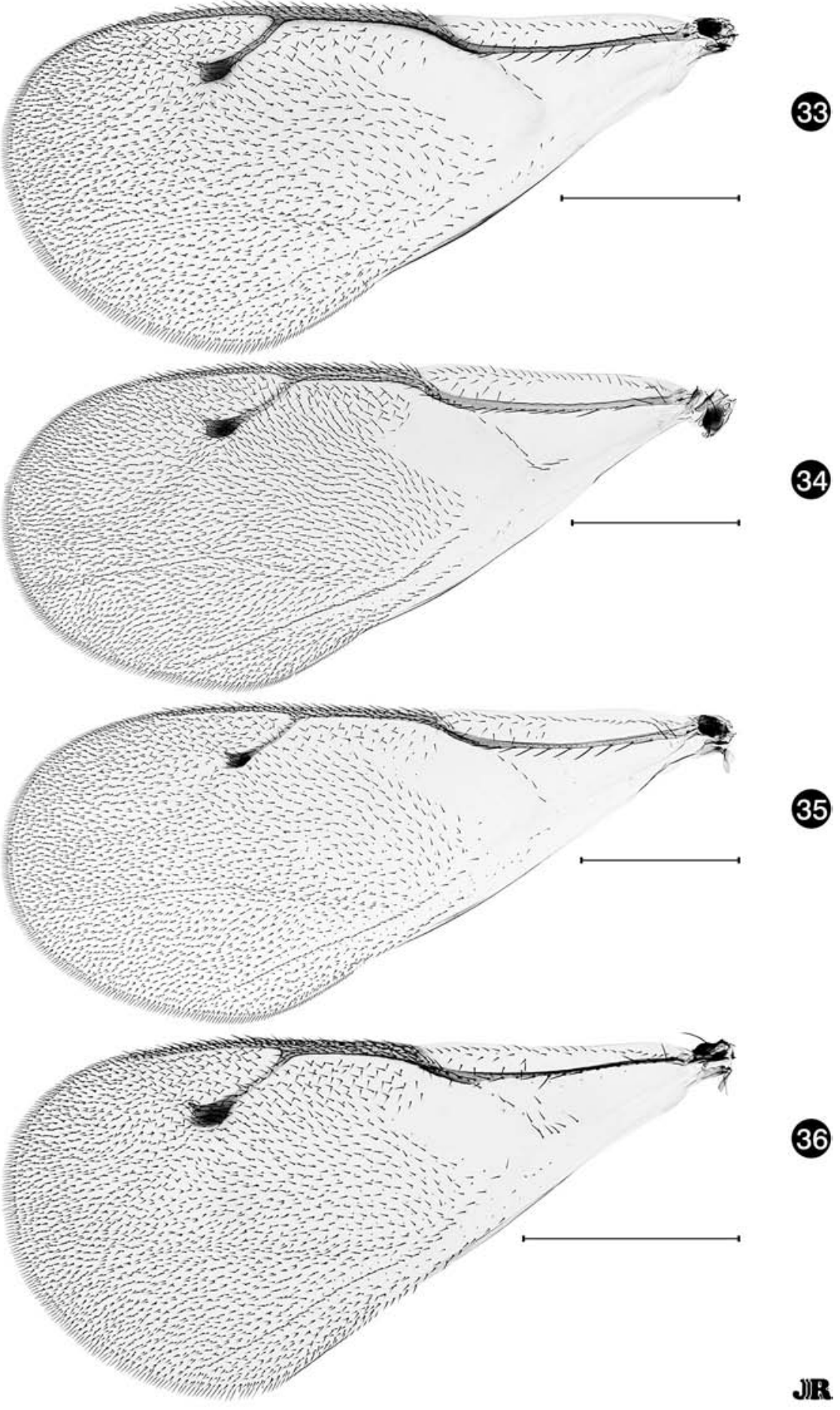


Muesebeck 1960), at which time he obtained for the USNM authoritatively identified specimens of some European species from the Gustav Mayr collection in Vienna, Austria. A single female from the Mayr collection bearing the label "Trichomalus fasciatus Th." is present in the USNM and it is likely that Gahan's identification was based on comparison of reared specimens with this female.

Buntin (1998) stated that T. perfectus represented $96 \%-100 \%$ of all parasitoids reared from canola seedpods infested with C. obstrictus near Griffon, Georgia, during 1994-1996; however, no Trichomalus species were found among 1124 voucher specimens (UGCA). The vast majority of specimens consist of Lyrcus maculatus (Gahan), which was recorded previously as a parasitoid of C. obstrictus in California (Carlson et al. 1951), Idaho (Walz 1957), and Washington (Hanson et al. 1948) under the generic names Trimeromicrus or Zatropis, both of which are now considered synonyms of Lyrcus (see Bouček 1993).

There is no evidence of T. lucidus in North America prior to the introduction of C. obstrictus, just as for M. moryoides. However, unlike $M$. moryoides, there is no conspicuous feature that distinguishes either sex of T. lucidus from other Trichomalus species. The Nearctic species remain unrevised and it is possible that specimens of $T$. lucidus collected prior to 1936 exist in collections. Although Delucchi and Graham (1956) suggested that literature records referring to $T$. fasciatus as a parasitoid of $C$. obstrictus were probably all based on misidentifications of $T$. perfectus, the rearings of Klander (2001) show that this is not necessarily true for Europe as well as for North America.

\section{Discussion}

Because of misidentifications, for over 60 years it was thought that the two principal biological control agents of the cabbage seedpod weevil in Europe, T. perfectus and M. morys, were present in North America and that they had been introduced with C. obstrictus. Our study disproves the first assumption and brings into question the second. Trichomalus perfectus and M. morys, in addition to Stenomalina gracilis (Walker, 1834) (Pteromalidae), are the most common and widespread chalcid biological control agents of
C. obstrictus in Europe (Murchie and Williams 1998; Williams 2003). The relative importance of the three species sometimes differs between localities and plant hosts surveyed in Europe, but it seems likely that at least one of the three species would have been introduced if parasitoids were introduced along with C. obstrictus. Although T. lucidus and N. tidius have both been reported as parasitoids of C. obstrictus in Europe, these records are very few. Furthermore, if M. moryoides is European in origin, then it must have a restricted distribution or be uncommon and thus not as likely to have been introduced as $M$. morys. Yet the fact remains that $M$. moryoides and $T$. lucidus are not known from North America prior to being reared from $C$. obstrictus soon after the introduction of this pest.

There are several possible explanations for what appears to be a major discrepancy between the principal chalcid species that parasitize $C$. obstrictus in Europe and those in North America. It could be that $N$. tidius, T. lucidus, and $M$. moryoides were all present in western North America on one or more noneconomic hosts prior to the introduction of $C$. obstrictus and expanded their host ranges to include this species once it became available; one or more of the species may be naturally occurring Holarctic species. This is unknown at present because Mesopolobus and Trichomalus are unrevised and Necremnus has not been revised comprehensively for North America. Alternatively, at least $N$. tidius and T. lucidus may have been introduced accidentally to North America prior to $C$. obstrictus along with some other ceutorhynchine host on some non-Brassica host plant. This latter hypothesis is supported by collection records of $N$. tidius in Idaho prior to the known introduction of $C$. obstrictus and by rearings of both $N$. tidius and T. lucidus in Europe from ceutorhynchine hosts on plants that were introduced to North America before C. obstrictus. Necremnus tidius was reared from C. typhae on shepherd's purse, whereas $T$. lucidus has been reared from $C$. alliariae, C. roberti, and $C$. scrobicollis on garlic mustard and from $M$. rugulosus on German chamomile and scentless chamomile (Kuhlmann et al. 2001; Muller et al. 2003). All of these plants were introduced to North America before C. obstrictus and may have been introduced along with some ceutorhynchine weevil and its parasitoids. It also remains possible that the complex of principal North American chalcid 
parasitoids differs from that indicated in the literature for Europe because different parasitoid complexes occur on different host plants or in different regions in Europe. For example, Kuhlmann et al. (2000) reported both $S$. gracilis and T. lucidus from C. obstrictus larvae reared from cabbage in Switzerland, but only $S$. gracilis from larvae reared from canola in Switzerland (Muller et al. 2004) and Germany (Kuhlmann et al. 2000). In contrast, Klander (2001) reported that $8 \%$ of the ectoparasitoids of $C$. obstrictus in canola in northern Germany were T. lucidus, compared with $75 \%$ T. perfectus, $8 \%$ M. morys, and $5 \%$ $S$. gracilis. The exact area in Europe from where $C$. obstrictus was introduced, and thus the prevalent parasitoid complex that might also have been introduced, remains unknown. It also seems very likely that $C$. obstrictus was introduced in cabbage or some other cole crop rather than in rape because the latter was not grown extensively in North America when the weevil was first discovered. However, most recent literature concerning parasitoids of $C$. obstrictus in Europe is based on rearings from rape and canola. A final major question that remains to be answered is the area of origin of M. moryoides - Nearctic or Palearctic. Answering these questions will require extensive host-parasitoid surveys of host weevils other than $C$. obstrictus and host plants other than canola in both western North America and Europe. It will also require comprehensive systematic revisions of relevant parasitoid genera, including analysis of genetic similarity between European and North American populations of $N$. tidius and $T$. lucidus, respectively, to investigate the possibility of sibling species.

\section{Acknowledgements}

We thank K. Bolte (Canadian Forest Service, Ottawa, Ontario) for the photographs of the forewings and J. Read (Agriculture and AgriFood Canada, Ottawa) for scanning electron microscopy and preparation of all plates of illustrations. We also gratefully acknowledge J. Noyes and S. Ryder (BMNH) and E. Grissell and M. Gates (USNM) for assistance during museum visits and the loan of material, as well as the following individuals for the loan of material on which this study was based: D. Buntin (UGCA), C. Hansson and R. Danielsson (MZLU), J. Leathers and S. Arnold (OSAC,
WFIC), J. McCaffrey and F. Merickel (WFBM), R. Zack (MTJP), S. Heydon (UCDC), and A. Ferguson and I. Williams (Institute of Arable Crops Research, Rothamsted, United Kingdom). The Alberta Agricultural Research Institute is also gratefully acknowledged for financial support of the junior authors.

\section{References}

Baker, Wm. W. 1936. Notes on a European weevil, Ceutorhynchus assimilis Payk., recently found in the state of Washington. The Canadian Entomologist, 68: 191-193.

Baird, A.B. 1949. The Canadian Insect Pest Review, 27: $268-288$.

Bouček, Z. 1959. A study of central European Eulophidae. I. Eulophinae (Hymenoptera). Sborník Entomologického Oddeleni Národního Musea v Praze, 33: 117-170.

Bouček, Z. 1993. New taxa of North American Pteromalidae and Tetracampidae (Hymenoptera), with notes. Journal of Natural History, 27: 12391313.

Bouček, Z., and Askew, R.R. 1968. Index of entomophagous insects. Palearctic Eulophidae (excl. Tetrastichinae). (Hym. Chalcidoidea). Le François, Paris.

Bouček, Z., and Heydon, S.L. 1997. Chapter 17. Pteromalidae. In Annotated keys to the genera of Nearctic Chalcidoidea (Hymenoptera). Edited by G.A.P. Gibson, J.T. Huber, and J.B. Woolley. NRC Research Press, Ottawa, Ontario. pp. 541692.

Bouček, Z., and Rasplus, J.-Y. 1991. Illustrated key to West-Palaearctic genera of Pteromalidae (Hymenoptera: Chalcidoidea). Institut National de la Recherche Agronomique, Paris.

Breakey, E.P., Webster, R.L., and Carlson, E.C. 1944. The cabbage seed pod weevil, Ceutorhynchus assimilis, in western Washington. Western Washington Experiment Station. Entomology. Bulletin of the Washington Agricultural Experiment Station, 455: 118-119.

Brodeur, J., Leclerc, L.-A., Fournier, M., and Roy, M. 2001. Cabbage seedpod weevil (Coleoptera: Curculionidae): new pest of canola in northeastern North America. The Canadian Entomologist, 133: 709-711.

Buntin, G.D. 1998. Cabbage seedpod weevil (Ceutorhynchus assimilis, Paykull) management by trap cropping and its effect on parasitism by Trichomalus perfectus (Walker) in oilseed rape. Crop Protection, 17: 299-305.

Buntin, G.D., McCaffrey, J.P., Raymer, P.L., and Romero, J. 1995. Quality and germination of rapeseed and canola seed damaged by adult cabbage seedpod weevil, Ceutorhynchus assimilis 
(Paykull) [Coleoptera: Curculionidae]. Canadian Journal of Plant Science, 75: 539-541.

Burks, B.D. 1979. Family Pteromalidae. In Catalog of Hymenoptera in America north of Mexico. Vol. I. Edited by K.V. Krombein, P.D. Hurd, D.R. Smith, and B.D. Burks. Smithsonian Institution Press, Washington, District of Columbia. pp. 768835.

Cárcamo, H.A., Dosdall, L., Dolinski, M., Olfert, O., and Byers, J.R. 2001. The cabbage seedpod weevil, Ceutorhynchus obstrictus (Coleoptera: Curculionidae) - a review. Journal of the Entomological Society of British Columbia, 98: 201210.

Carlson, E.C., Lange, W.H., Jr., and Sclaroni, R.H. 1950. Brussels sprouts seed loss in California caused by the cabbage seedpod weevil. Journal of Economic Entomology, 43: 389-390.

Carlson, E.C., Lange, W.H., Jr., and Sclaroni, R.H. 1951. Distribution and control of the cabbage seedpod weevil in California. Journal of Economic Entomology, 44: 958-966.

Colonnelli, E. 1998. Systematic and synonymic notes on Ceutorhynchinae, with lectotype and neotype designations, and descriptions of three new genera (Coleoptera, Curculionidae). Fragmenta Entomologica, 30: 105-175.

Cory, E.N., and Muesebeck, C.F.W. 1960. Arthur Burton Gahan 1880-1960. Proceedings of the Entomological Society of Washington, 62: 198-204.

Crowell, H.H. 1952. Cabbage seedpod weevil control with Parathion. Journal of Economic Entomology, 45: 545-546.

Dalla Torre, K.W. von. 1898. Catalogus Hymenopterorum hucusque descriptorum systematicus et synonymicus. V. Chalcididae et Proctotrupidae. Lepzig.

Delucchi, V., and Graham, M.W.R. de V. 1956. La révision du genre Trichomalus Thomson (1878) (Chalcidoidea: Pteromalidae). Beiträge zur Entomologie, 6: 543-576.

Dosdall, L.M., Moisey, D., Cárcamo, H., and Dunn, R. 2001. Cabbage seedpod weevil factsheet. Agdex 622-21, Alberta Agriculture, Food and Rural Development, Edmonton, Alberta.

Doucette, C.F. 1948. Field parasitization and larval mortality of the cabbage seedpod weevil. Journal of Economic Entomology, 41: 765-767.

Doucette, C.F. 1944. The cabbage seedpod weevil, Ceutorhynchus assimilis (Payk). Western Washington Experiment Station. Entomology. Bulletin of the Washington Agricultural Experiment Station, 455: 123-125.

Förster, A. 1841. Beiträge zur monographie der Pteromalinen Nees 1 Heft. Aachen.

Frankton, C., and Mulligan, G.A. 1971. Weeds of Canada. Publication 948, Canada Department of Agriculture, Ottawa, Ontario.

Gahan, A.B. 1941. A revision of the parasitic wasps of the genus Necremnus Thomson (Eulophidae;
Hymenoptera). Journal of the Washington Academy of Sciences, 31: 196-203.

Gibson, G.A.P. 1995. Parasitic wasps of the subfamily Eupelminae: classification and revision of world genera (Hymenoptera: Chalcidoidea, Eupelmidae). Memoirs on Entomology International, 5: 1-421.

Gibson, G.A.P. 1997. Chapter 2. Morphology and terminology. In Annotated keys to the genera of Nearctic Chalcidoidea (Hymenoptera). Edited by G.A.P. Gibson, J.T. Huber, and J.B. Woolley. NRC Research Press, Ottawa, Ontario. pp. 16-44.

Gibson, G.A.P. 2003. Phylogenetics and classification of Cleonyminae (Hymenoptera: Chalcidoidea: Pteromalidae). Memoirs on Entomology International, 16: 1-339.

Gibson, G.A.P., and Baur, H. 2005. Mesopolobus trasullus (Walker, 1839), a valid species and senior synonym of Mesopolobus roseni Graham, 1984. Entomologist's Gazette, 56: 129-132.

Gomez, J.M., and Zamora, R. 1994. Top-down effects in a tritrophic system: parasitoids enhance plant fitness. Ecology, 75: 1023-1030.

Goureau, C.C. 1851. Mémoire pour servir à l'histoire des Diptères don't les larves minent les feuilles des plantes et à celle de leurs parasites. Annales de la Société Entomologique de France, 9(2): 131-176, 3 plates.

Graham, M.W.R. de V. 1956. A revision of the Walker types of Pteromalidae (Hym., Chalcidoidea). Part 2 (including descriptions of new species). Entomologist's Monthly Magazine, 92: 246-263.

Graham, M.W.R. de V. 1957. A revision of the Walker types of Pteromalidae (Hym., Chalcidoidea). Part 3 (including descriptions of new species). Entomologist's Monthly Magazine, 93: 217-236.

Graham, M.W.R. de V. 1959. Keys to the British genera and species of Elachertinae, Eulophinae, Entedontinae, and Euderinae (Hym., Chalcidoidea). Transactions of the Society for British Entomology, 13: 169-204.

Graham, M.W.R. de V. 1963. Additions and corrections to the British list of Eulophidae (Hym., Chalcidoidea). Transactions of the Society for British Entomology, 15(9): 167-275.

Graham, M.W.R. de V. 1969. The Pteromalidae of north-western Europe (Hymenoptera: Chalcidoidea). Bulletin of the British Museum (Natural History) Entomology, 16(Suppl.): 1-908.

Graham, M.W.R. de V. 1984. New Chalcidoidea (Insecta: Hymenoptera) mainly from France, including several species of Eurytoma and Pteromalus associated with Euphorbia. Journal of Natural History, 18: 495-520.

Graham, M.W.R. de V. 1991. Type material in the University Museum, Oxford, of one Kirby and five Walker species of Eulophidae (Hym., Chalcidoidea) with new synonymy and designation of 
lectotypes. Entomologist's Monthly Magazine, 127: 7-9.

Hanson, A.J., Carlson, E.C., Breakey, E.P., and Webster, R.L. 1948. Biology of the cabbage seedpod weevil in northwestern Washington. State College of Washington Agricultural Experimental Station Bulletin, 498: 1-15.

Harmon, B.L., and McCaffrey, J.P. 1997. Parasitism of adult Ceutorhynchus assimilis (Coleoptera: Curculionidae) by Microctonus melanopus (Hymenoptera: Braconidae) in northern Idaho and eastern Washington. Journal of Agricultural Entomology, 14: 55-59.

Heymons, R. 1921. Mitteilungen über den Rapsrüssler, Ceutorhynchus assimilis Payk. und seinen Parasiten, Trichomalus fasciatus Thoms. Zeitschrift für Angewandte Entomologie, 8: 93 111.

Klander, B. 2001. Die Rüsselkäfer der Unterfamillie Ceutorhynchinae und deren Parasitoide auf Winterraps und begleitenden Unkräutern in Schleswig-Holstein. M.Sc. thesis, ChristianAlbrechts-Universität, Kiel, Germany.

Kuhlmann, U., Toepfer, S., Grossrieder, M., White, H., Klander, B., Reimer, L. et al. 2000. Summary report - progress in 2000. Agricultural pest research. CABI Bioscience Switzerland Centre, Delémont, Switzerland.

Kuhlmann, U., Toepfer, S., Grossrieder, M., Zhang, F., Hunt, E., Hemachandra, K.S. et al. 2001. Summary report - progress in 2001. Agricultural pest research. CABI Bioscience Switzerland Centre, Delémont, Switzerland.

Kuhlmann, U., Dosdall, L.M., and Mason, P.G. 2002. 11. Ceutorhynchus obstrictus (Marsham), cabbage seedpod weevil (Coleoptera: Curculionidae). In Biological control programmes in Canada, 1981-2000. Edited by P.G. Mason and J.T. Huber. CABI Publishing, Wallingford, United Kingdom. pp. 52-58.

Laborius, A. 1972. Untersuchungen über die Parasitierung des Kohlschotenrüsslers (Ceutorhynchus assimilis Payk.) und der Kohlschotengallmücke (Dasyneura brassicae Winn.) in Schleswig-Holstein. Zeitschrift für Angewandte Entomologie, 72: 14-31.

Mason, P.G., Baute, T., Olfert, O., and Roy, M. 2004 (2003). Cabbage seedpod weevil, Ceutorhynchus obstrictus (Marsham) (Coleoptera: Curculionidae) in Ontario and Quebec. Journal of the Entomological Society of Ontario, 134: 107-113.

McKenna, D. 1992. Study of the effects of insecticide management on the seedpod weevil (Ceutorhynchus assimilis Payk.) and its parasites. M.Sc. thesis, University of London, London.

McLeod, J.H. 1951. Biological control investigations in British Columbia. Proceedings of the Entomological Society of British Columbia, 47: 27-36.

McLeod, J.H. 1953. Notes on the cabbage seedpod weevil, Ceutorhynchus assimilis (Payk.)
(Coleoptera: Curculionidae), and its parasites. Proceedings of the Entomological Society of British Columbia, 49: 11-18.

McLeod, J.H. 1962. Part I. Biological control of pests of crops, fruit trees, ornamentals and weeds in Canada up to 1959. In A review of the biological control attempts against insects and weeds in Canada. Technical Communication No. 2, Commonwealth Institute of Biological Control, Trinidad. Commonwealth Agricultural Bureaux, Farnham Royal. pp. 1-33.

Miczulski, B. 1968. Community studies on Hymenoptera found on Brassica napus L. Part VI. Chalcidoidea. Polskie Pismo Entomologiczne, 38: 341-385. [Polish with English summary.]

Muller, F., Gariepy, T.D., and Kuhlmann, U. 2003. Biological control of cabbage seedpod weevil, Ceutorhynchus obstrictus. Annual report 20022003. CABI Bioscience Switzerland Centre, Delémont, Switzerland.

Muller, F., Cuenot, E., and Kuhlmann, U. 2004. Cabbage seedpod weevil (Ceutorhynchus obstrictus Marsham). Annual report 2003-2004. CABI Bioscience Switzerland Centre, Delémont, Switzerland.

Murchie, A.K., and Williams, I.H. 1998. A bibliography of the parasitoids of the cabbage seed weevil (Ceutorhynchus assimilis Payk.). IOBC/WPRS Bulletin, 21(5): 163-169.

Nasredlin, N. 1973. A study of the weevil complex on mustard with special reference to the seedpod weevil. Ph.D. thesis, University of London, London.

Noyes, J.S. 2002. Interactive catalogue of world Chalcidoidea. 2nd ed. [CD-ROM]. Taxapad, Vancouver, British Columbia, and The Natural History Museum, London.

Peck, O. 1963. A catalogue of the Nearctic Chalcidoidea (Insecta; Hymenoptera). The Canadian Entomologist, 30(Suppl.): 1-1092.

Ryan, R.B., Bousfield, W.E., Johanningmeier, C.W., Parsons, G.B., Schmitz, R.F., and Theroux, L.J. 1977. Releases of recently imported larch casebearer parasites for biological control in the western United States, including relocations of Agathis pumila. United States Forest Service Research Note PNW-290.

Schauff, M.E., LaSalle, J., and Coote, L.D. 1997. Chapter 10. Eulophidae. In Annotated keys to the genera of Nearctic Chalcidoidea (Hymenoptera). Edited by G.A.P. Gibson, J.T. Huber, and J.B. Woolley. NRC Research Press, Ottawa, Ontario. pp. 327-429.

Spaic, I. 1972. Prilog poznavanjii parazita jelinog iglivcara Argyresthia fundella F.R. Acta Entomologica Jugoslavica, 8: 99-103.

Thomson, C.G. 1878. Hymenoptera Scandinaviae 5. Pteromalus (Svederus) continuatio. Lund.

Walker, F. 1834. Monographia Chalciditum. Entomological Magazine, 2: 340-369. 
Walker, F. 1835. Monographia Chalciditum. Entomological Magazine, 2: 476-502.

Walker, F. 1836. Monographia Chalciditum. Entomological Magazine, 3: 465-496.

Walker, F. 1839. Monographia Chalciditum 1. London.

Walker, F. 1848. List of the specimens of Hymenopterous insects in the collection of the British Museum. E. Newman, London.

Walz, A.J. 1957. Observations on the biologies of some hymenopterous parasites of the cabbage seedpod weevil in northern Idaho. Annals of the Entomological Society of America, 50: 219-220.
Warwick, S.I., Francis, A., and Mulligan, G.A. 2004. Brassicaceae of Canada [online]. Agriculture and Agri-Food Canada. Available from http://www. scib.gc.ca/spp_pages/brass/index_e.php [accessed August 2004].

Westwood, J.O. 1833. Descriptions of several new British forms amongst the parasitic hymenopterous insects. Philosophical Magazine, 3(3): 342-344.

Williams, I.H. 2003. Parasitoids of cabbage seed weevil. In Biocontrol of oilseed rape pests. Edited by D.V. Alford. Blackwell, Oxford. pp. 97-112. 